\title{
Article \\ The Impact of Clay Minerals on the Building Technology of Vernacular Earthen Architecture in Eastern Austria
}

\author{
Hubert Feiglstorfer ${ }^{1, *}$ and Franz Ottner ${ }^{2}$ (D) \\ 1 Austrian Academy of Sciences, 1020 Vienna, Austria \\ 2 Department of Water, Atmosphere and Environment, University of Natural Resources and Life Sciences \\ Vienna, Muthgasse 18, 1190 Vienna, Austria; franz.ottner@boku.ac.at \\ * Correspondence: hubert.feiglstorfer@oeaw.ac.at
}

check for updates

Citation: Feiglstorfer, H.; Ottner, F. The Impact of Clay Minerals on the Building Technology of Vernacular Earthen Architecture in Eastern Austria. Heritage 2022, 5, 378-401. https://doi.org/10.3390/ heritage 5010022

Academic Editors: Carlos Alves, Carlos Figueiredo and

Jorge Sanjurjo-Sánchez

Received: 14 December 2021

Accepted: 30 January 2022

Published: 21 February 2022

Publisher's Note: MDPI stays neutral with regard to jurisdictional claims in published maps and institutional affiliations.

Copyright: () 2022 by the authors. Licensee MDPI, Basel, Switzerland. This article is an open access article distributed under the terms and conditions of the Creative Commons Attribution (CC BY) license (https:// creativecommons.org/licenses/by/ $4.0 /)$.

\begin{abstract}
The vernacular architecture in many regions in Eastern Austria was characterized by the use of unfired clay, at least until the 19th century, and in some areas until the 20th century. Farmhouses and associated farm buildings, such as storage buildings or press houses for the production of wine and cider, were erected using different earth construction techniques. The study area stretches from the Weinviertel, a region located in the province of Lower Austria in the north-east of Austria, to the Burgenland, a region located in the south-east of Austria, which belonged to Western Hungary until 1921. From a geological point of view, in the east of Austria-in the Vienna Basin and the Molasse Zone-huge areas of Tertiary clay are covered with loess deposits, which is the best-known basic material used in local earth-building traditions. A core question in the research on vernacular earthen heritage focuses on the impact of the geological conditions in Eastern Austria on the local earth-building techniques. The mineralogical composition of the different clays had an impact on the local building techniques. From a material-culture point of view, research on the relationship between the mineralogical properties of clay resources and local building techniques sheds light on the factors which influenced the evolution of certain vernacular building features. Tertiary clays and loess from the Pleistocene favoured the making of earth lumps, cob walls and adobe bricks over the whole Eastern Austrian region. Contrarily, regions in Burgenland with a high amount of gravel preferred, by tradition, to make walls by ramming. The clay mineral smectite acts as a binding agent in earth-building techniques over the whole investigated region-Weinviertel, Burgenland and Western Hungary.
\end{abstract}

Keywords: material culture; vernacular architecture; earthen architectural heritage; clay mineralogy; Weinviertel; Burgenland; Eastern Austria

\section{Introduction}

The properties of the raw materials used for building purposes are crucial to understanding the technologies used in historical building structures. The type and quantity of clay minerals affect the physical behaviour of clay as a building material, e.g., its abilities to transport and store humidity, or to swell and shrink [1,2]. One notable difference between clay and other commonly used solid natural building materials such as timber or stone is clay's capacity to reversibly transform from a solid to a plastic consistency, and vice versa. Unlike timber and stone, clay minerals can be mixed with organic fibrous materials such as straw or hemp, etc., in order to temper and reinforce it. Traditional knowledge about the workability of particular types of clay allows for a technical optimization of traditional earth-building methods. The present research is the first of its kind to be conducted in Eastern Austria. Key publications on earth-building in Eastern Austria are collected here [3-9].

A lot of research and publications on traditional earth-building techniques have been carried out and published internationally $[1,10]$, but little research has been conducted on 
the influence of clay minerals on traditional building techniques, for example, in Portugal or Italy. The relationship between clay minerals and traditional building techniques was included by Costa et al. in the publication 'Influence of the mineralogical composition on the properties of adobe blocks from Aveiro, Portugal' [11]. In this article, two different areas of Portugal were compared according to grain-size distribution, bulk and clay mineral analysis, compressive strength, and water absorption. In another article, Costa et al. discussed the sustainable use of traditional geomaterials in construction practice [12]. An example for the material research on earth from Italy in the context of architectural conservation is given by Fratini et al., with their publication in 2011, titled 'The earth in the architecture of the historical centre of Lanezia Terme (Italy): Characterization for restoration' [13]. The investigations mentioned above used clay mineralogical analyses, among other laboratory methods. The results have a local reference due to the local raw material in each case.

The highly sophisticated examination methods involved and the need for laboratory equipment may be among the reasons why the aspects of clay mineralogy in building heritage are often neglected. In addition to cultural, historical, economic, or social factors, vernacular building methods were also strongly influenced by local geology and forest cover. As a hypothesis, the clay mineralogical properties of local clays affected local earthbuilding methods. One of the main aims of this article is to examine the relationship between the mineralogical properties of the clay and local earth-building traditions.

Our approach to this problem involves presenting local basics-including a description of the traditional earth-building techniques-and the environmental influences on their evolution, such as geography and regional earth-building techniques. This first step is essential for the understanding of the criteria for sample selection. These basic data form the basis of the research hypothesis, and the research methods will be presented. In a final step, the results of the clay mineralogical analyses are presented and contextualised with the technical features of local building techniques.

\section{Regional Earth-Building Techniques}

In this chapter, the different earth-building techniques and their regional context are presented and described in detail using specific research locations. For a more detailed observation of the history of vernacular architecture, publications [2-9] are recommended. Based on these publications, the present article goes a step further and touches the mineralogical side of earth-building techniques. In-situ examinations of historical earth buildings enabled the authors to gain scientific insights into the construction of numerous vernacular earth-building techniques [6,9]. The observation of buildings and their components, together with the sampling of the clay of those building components and clay pits, indicated that the local population possessed a certain level of technical know-how regarding clay processing [14]. The traceability of historical craft techniques allows us to create a holistic picture of the history of vernacular construction technology.

A team of specialists in clay mineralogy and earth-building techniques who together formed a group, the ARGE Lehmbau BOKU team at the University of Natural Resources and Life Sciences, carried out research on historical earth-processing techniques [3]. The mapping of historical earth buildings resulting from a Citizen Science project gave a basic overview of the existing earth buildings and allowed the researchers to draw on information given by the local population. This so-called "Lehmbaukataster" (earth building cadastre) constitutes a comprehensive basis for comparative earth-building research in the Weinviertel [3].

The samples originate from objects which were made of clay [6]: (a) Earth lumps (locally known as "Lehmwuzel") are shaped by hand, mixing clay, straw and water. These ingredients are put together in a humid state. In contrast to earth lumps, (b) adobe bricks are made with a certain module size. In Eastern Austria, adobe bricks are mostly made without adding straw. Furthermore, in contrast to earth lumps, adobe bricks are dried before the wall is erected. (c) Cob walls (locally known as "gesatzte Mauer") are made of a 
similar mixture to that described for the earth lumps. Contrary to earth lumps, the wall is erected by piling it up layer by layer with a pitchfork. (d) Rammed-earth walls are made of earth-moist clay in a formwork without adding straw or water. The single layers of clay are compressed with a ramming tool. (e) Earth plaster, which is a mixture of clay, straw and water, is traditionally added onto walls made of adobe bricks, earth lumps and cob walls, while rammed-earth walls are in some cases kept unplastered. Specifically in Southern Burgenland, we found several examples of wooden log buildings which were covered with a clay plaster, and finally the latter was covered with a clay slurry.

An experimental reconstruction of earth-building components using original clay blends taken from other sites allowed us to gain significant insights into the historical processing techniques used in Eastern Austria [6]. Based on these studies, we can state as a general conclusion that traditional processing was always dependent on and adapted to the local availability of certain types of clay. Accordingly, the ratios for mixing the clay with organic fibres for tampering were traditionally aligned with the physical properties of the respective available clays. In various rural buildings, we can see that different earth-building techniques were used in one and the same building [15]. This indicates that the choice of a specific constructive type of clay-based building component did not only depend on the quality of the locally available clay.

The predominant type of wall construction found over Eastern Austria made use of adobe bricks. To a lesser extent, earth lumps and cob walls can also be found in many parts of Eastern Austria, while rammed-earth walls are not existent in the Weinviertel, and only in Burgenland [6].

On the one hand, the construction had to comply with static and process sequencerelated parameters. The farmhouse at Hauptstrasse 16 in Großriedenthal, for example, used earth lumps known as "Lehmwuzel" in the upper wall section, where they were easier to transport than the monolithic cob walls, which were primarily used in the lower wall section. On the other hand, general developments in the manufacture of mass building products influenced vernacular earth-building techniques at least from the early 19th century onwards. Many of the structures were built with adobe bricks, and represent a structural transition from earth lumps and cob walls to the use of fired bricks. The regional development of certain building traditions, such as the ramming of a cob wall in a formwork, or stacking it without a formwork, compressing it by stepping on it or using wooden boards, or just not compressing the wall [9], are regional building culture developments. The type of organic fibres added to the clay-be it straw, chaff, cow dung, or juniper rods, etc.- - depended on the one hand on local availability, and on the other hand on local customs.

Furthermore, solid earth-building techniques were primarily used, in particular those that were used to erect walls, but also for infilling post constructions and post and beam constructions [6]. We also focused on the clay coatings, especially those like clay plaster or clay slurry, used on log constructions (note: rammed-earth floors and earth seals on the top-floor ceiling earth-building techniques are not dealt with in this section. These are discussed elsewhere in a further contribution on floors and ceilings). In contast to the log constructions, wattle walls primarily have a wooden frame construction with the wattle in between, on which clay coatings were applied, or they were just left uncoated to provide natural ventilation in a room. For a description of local earth-building techniques, see [6].

\section{Geography and Geology}

Vernacular earth-building techniques are shaped by different influences, both natural and anthropogenic. The delimitation of the study region plays a decisive role in the concrete assignment of certain earth-building techniques, in particular to Eastern Austria, which is traditionally Austria's main earth-building region [6].

This study focuses on the Weinviertel and Burgenland, the two regions in Austria that definitely have earth-building traditions. At the same time, these traditions do not end at political borders, but in some cases extend far into neighbouring areas. The Weinviertel, for 
example, is bordered by earth-building regions such as Moravia in the north, and Slovakia in the east. In the adjacent wooded and rocky areas of the Waldviertel in the west or the rocky areas in the south, bordering Northern Burgenland, earth-building traditions are either subordinate or non-existent. Adjacent to Burgenland, earth-building traditions can be found in Western Hungary in the east, in contrast to the densely-wooded Austrian province of Styria in the west.

When exploring these two regions, one of the results of our research was the observation of a small-scale regional development of local traditional earth-building techniques. A differentiation between the earth-building locations in the Weinviertel cannot be made quantitatively with today's state-of-the-art methods-i.e., according to whether settlements were founded on earth-building traditions or not-but rather, this must be done qualitatively, i.e., according to the type of different earth-building techniques that are used on a small regional scale [3,6]. This differentiation is again not based on clear regional boundaries, but rather on the flowing transitions of a changing predominance of earth-building techniques, whereby several techniques within these regions may exist as indigenous traditions alongside each other.

In the research area, there is still a small regional dominance of certain earth-building techniques, but the overall number of vernacular earthen buildings in Burgenland is generally strongly reduced. The fact that Burgenland was part of Hungary until 1921 necessitates that we study today's historical architecture from the 19th century and before from a Hungarian or an Austro-Hungarian perspective. That the Burgenland has a different political, social and economic history compared to the Weinviertel is evidenced by the different ways of representing social status and access to building materials as provided by the feudal lord; these and other factors influenced the evolution of different building techniques or the time period of their replacement by industrially-prefabricated products such as fired bricks.

Unlike the Weinviertel, where earth-building can be said to predominate in the entire area, Burgenland showed a small-scale development of log buildings alongside earth buildings [6]. The transition from vernacular log- or earth-building techniques to the use of prefabricated building materials such as fired bricks or imported building materials is connected to more widespread travel and trade. While in the Weinviertel we could only find evidence of one log construction (in the region of Retz), in Burgenland, in particular in the first half of the 19th century, there was a regional predominance of timber buildings in South-Burgenland. Nevertheless, in the regions of Burgenland where vernacular buildings predominated up to the 19th century, we observed small-scale regional differences between different earth-building techniques [6].

\subsection{Geology of the Weinviertel in Lower Austria}

The geology of the Weinviertel, the north-eastern part of Austria, is dominated by two large tectonic units: the Vienna Basin in the east and, separated by the Waschberg Unit, the Molasse Zone in the west (Figure 1a). The Vienna Basin is a pull-apart basin at the junction of the Alps in the west and the Carpathians in the east [16]. It is about $200 \mathrm{~km}$ long and $50 \mathrm{~km}$ wide, and reaches to the Czech Republic in the north and Slovakia in the east. It was covered by a large historical ocean, the Parathetys. Large amounts of marine sediments were deposited during Tertiary time. Very fine-grained sediments-clays and marls_-were deposited at the centre of the basin.

The Molasse Zone is the western part of the Weinviertel. It was developed during the Paleogene period, and was caused by plate tectonic activities. The area was also covered by the shallow Parathetys Ocean. Over a long period of time, large amounts of sediment were deposited in this ocean. Similarly to the Vienna Basin, very fine-grained material was deposited. One of the best-known pelitic sediments, called "Schlier" in German, is a widespread clay/marl, and in the past it was used for brick making. Only a few clay pits are still in use. 


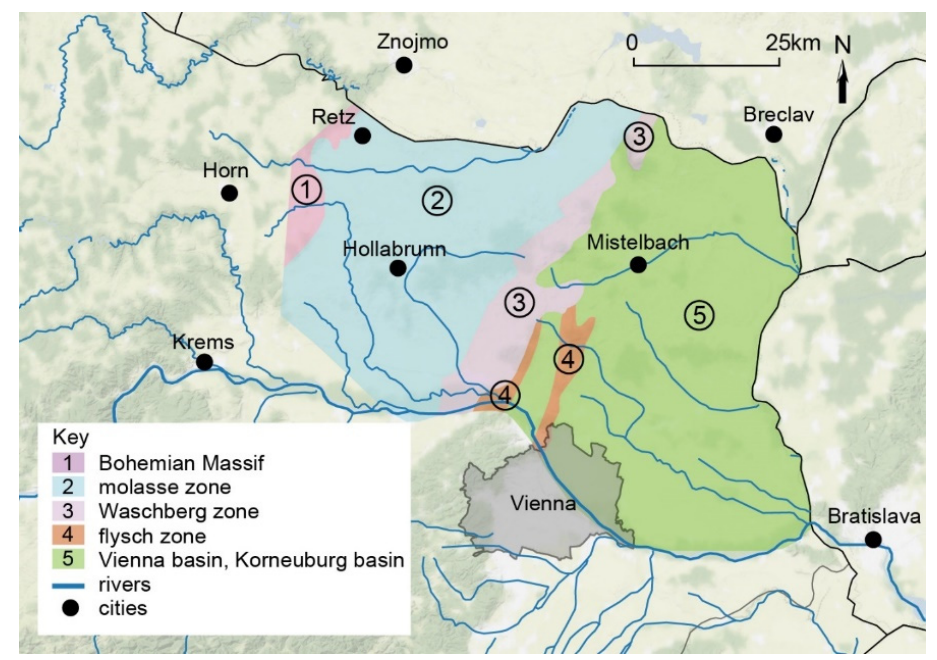

(a)

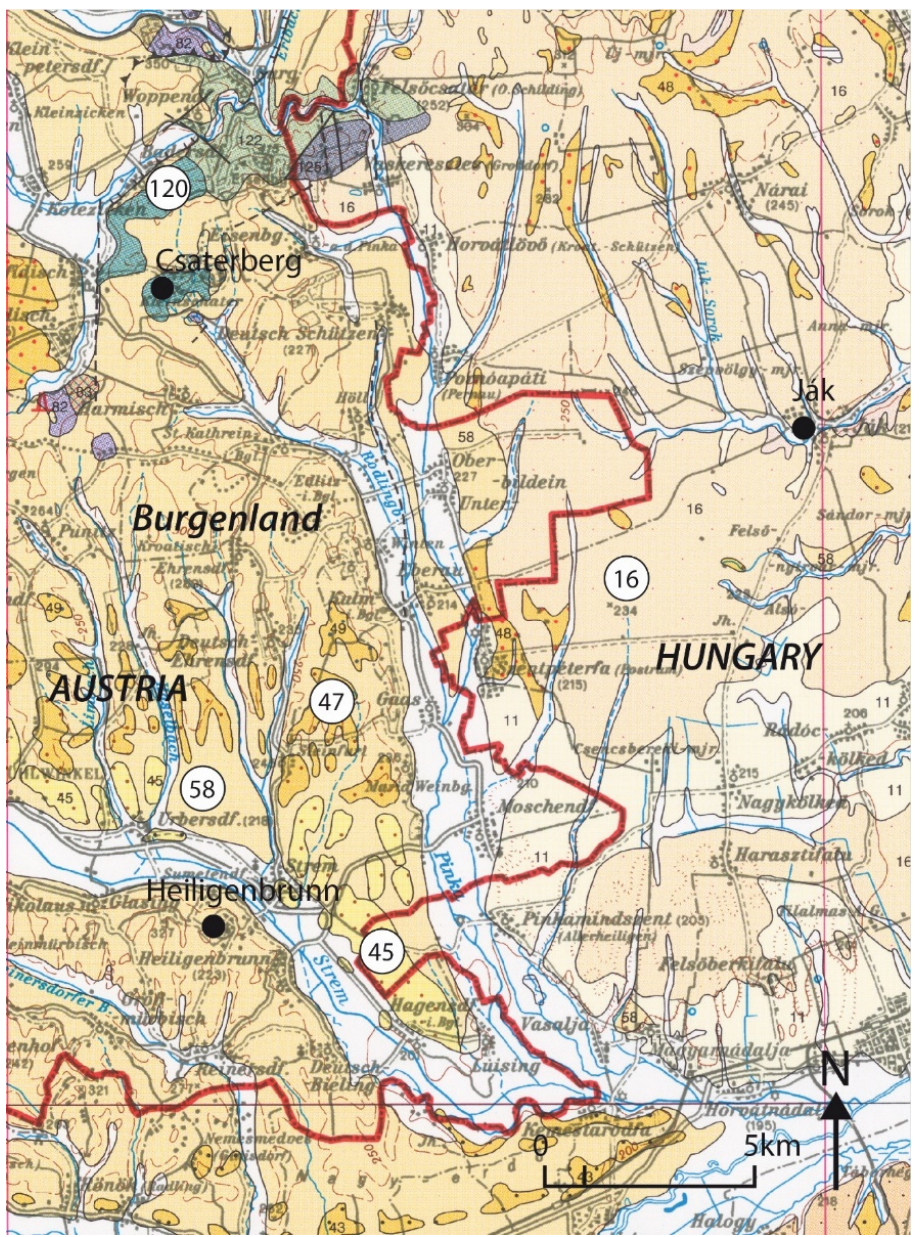

(b)

Figure 1. (a) Geological map of the Weinviertel (Image source: @ Roland Meingast, Hubert Feiglstorfer and Jakob Gredler according to [6]; the geological zones are given according to Heinrich, Hofmann and Roetzel 2004 [17]). (b) Geological map of Southern Burgenland. Key: $16=$ loess and loessclay; 45 and 47 = gravel covered by silt; 58 = sediments, undifferentiated (clay, sand, and gravel); 120 = serpentinite (Image source: (C) Hubert Feiglstorfer based on geological map: (c) Geologische Bundesanstalt, Wien). 
The Waschberg Unit consists of marine limestone, and separates the eastern and western part of the Weinviertel. Only a small strip parallel to the Waschberg unit is part of the Flysch unit. The Bohemian Massif represented by the Manhartsberg constitutes the border to the Waldviertel in the most western part.

During the Ice Age, the Weinviertel was not covered by glaciers. Large amounts of dust were blown by the wind during that cold period, and sedimented as loess in that area. This sediment is now the typical cover of the whole Weinviertel [17].

The mineralogical composition of loess is quartz, feldspars, mica, calcite, dolomite, clay minerals and some additional rare minerals. The grain-size distribution of loess consists mainly of silt and smaller amounts of clay and sand. Coarser parts cannot be transported by wind.

The loess from the Weinviertel is also an excellent raw material for construction. In the clay fraction of the local loess, adequate amounts of the clay mineral smectite are present, which is very important for the good quality of earth buildings.

In some areas of the Weinviertel, the loess cover is eroded and the older clays from the Parathetys can be found. Such typical clayey sediments occur in various formations, e.g., in the Laa Formation, the Grund Formation, and the Zellerndorf Formation, etc.

\subsection{Geology of the Sampling Sites in Weinviertel}

In this section, we take a closer look at the geology of the regions where the samples originated.

Obersulz and Niedersulz

Surrounded by loess and loess clay, Obersulz and Niedersulz are located on sediments of the Pannonian, i.e., clayey-silty, sandy and gravelly sediments [18] (p. 31).

Erdpress

Surrounded by loess and loess clay, Erdpress is located in an area characterised by clay, and weathered clay [18]. In the immediate vicinity, there are islands with elevated terrace sediments made of gravel and sand, partly solidified, i.e., quartzrich gravel and sand, or coarse and local gravel which is located significantly higher [18] (p. 22). A colourful series of clay with different colours the" red clay formation" is situated in the West [19].

Großriedenthal

Großriedenthal is located in the Weinviertel loess region, locally with paleo soils, solifluction material and surface-flushing sediments [20]. Großriedenthal is bordered by the Hollabrunn-Mistelbach Formation in the east, fluvial deposits from the paleo Danube [20].

Oberdürnbach

Oberdürnbach is located at the junction of Weinviertel and Waldviertel at the foot of the Manhartsberg, which is characterised by biotite granite and delimits the western edge of the Weinviertel loess region, locally containing paleo soils, silty and sandy soils, and crystalline fragments [21].

Ronthal

Ronthal is located at the junction of the Hollabrunn-Mistelbach Formation, and often features sloping and partly sandy gravel and sand in the east [18] (p. 24), and Gföhler Gneis from the Bohemian Massif in the west.

\subsection{Geology of the Burgenland}

Burgenland, which is located on the eastern border of the Alps at the seam to the Hungarian lowland, has an extraordinary shape, elongated in the north-south direction and rather narrow in the east-west direction (Figure 1b). The narrowest part is only $5 \mathrm{~km}$ wide, whereas the widest part-in North Burgenland, in the area of Illmitz-is up to about 
$55 \mathrm{~km}$ wide. Its elongation gives it a rather complex geology, which is evidence of the variety of different geological units that can be found in Burgenland [22].

The middle part of Burgenland is home to the most eastern part of the Eastern Alps, which is called the "Zentralzone". It consists of several tectonic units, including the Penninicum, the Wechsel Unit and the Grobgneis Unit. Rocks from the Paleozoic age (>250 Ma. years) are dominant [23]. The Penninicum, the deepest unit, is the continuation of rocks from the "Hohen Tauern" in Western Austria, and it crops out in the four geological windows Rechnitz, Bernstein, Möltern and Eisenberg.

In the northern and southern parts of Burgenland, there are young basins dating from the Tertiary Period. Those young basins—-the Vienna and Eisenstädter Mattersburger Basins-are filled with fine-grained sediments which are very useful for adobe constructions.

During the Neogene, volcanic activity took place: basalts are known from Pauliberg, Stoob and Oberpullendorf, and are around 11 million years old. Much younger volcanic rocks, about 2 million years old, can be found in the southern part of Burgenland, e.g., Tobaj, Neuhaus and Güssing.

Like the Weinviertel, loess was sedimented during the Ice Age in all parts of Burgenland, although it is not as widespread as that in the Weinviertel.

In Burgenland, suitable clays for earth constructions can be found in the areas with loess, and in distinct places where fine-grained marine sediments occur. Frequently, additional raw material which is useful for earth-building can be found on top of mica schists and gneisses, where the weathering products of the micas have accumulated since the Tertiary Period.

The different earth-building techniques are possibly the result of the geological varieties in the qualities of different clays. Adobe technology needs a relatively fine-grained raw material, unlike the rammed-earth technique, which requires a lot of sand and gravel, and does not work using only fine-grained clay.

\subsection{Geology of the Sampling Sites in Burgenland and Western Hungary}

In the following section, we take a closer look at the geology of the regions where the samples originated.

Heiligenbrunn

Heiligenbrunn is located in an environment which is a mixture of clay, sand and gravel, which covers a wide area of Southern Burgenland [24].

\section{Csaterberg}

About $16 \mathrm{~km}$ north of Heiligenbrunn is the wine region of Csaterberg, where the geology becomes more volcanic, with tuff stone and basaltic material, which stems from powerful, long-term eruptions [24] (p. 28). In the Stone Museum in Csaterberg, the freshwater opal is mentioned as the main material covering the surface of the Csaterberg [24] (p. 116). This section of the so-called "Rechnitzer Einheit", like Heiligenbrunn, is embedded in Tertiary sediments [24] (p. 114).

Ják

About $16 \mathrm{~km}$ east of Csaterberg lies the village of Ják, located along a fluvial sediment within a wide loess region, which-roughly along the Austrian border-becomes the Tertiary Southern Burgenland clay-sand-gravel region [25].

\section{Material and Methods}

A significant set of samples of the different local earth-building techniques and from local clay pits was gathered, and finally, 19 samples were examined. The samples were collected during several interventions, originally by the authors with regard to the present study, and by students for bachelor's and master's theses at university. The sampling was conducted by hand, and - if needed-also with shovels, trowels and hammers. 


\subsection{Material}

The samples were selected along different geological zones, starting from Central Weinviertel and moving to Western Weinviertel at the border to the Waldviertel. In Burgenland, we started with the southern region, and moved towards the Austrian-Hungarian border region just across from Western Hungary (Figure 2, Table 1).

Table 1. Analysed samples from Weinviertel, Burgenland and West Hungary.

\begin{tabular}{|c|c|}
\hline Lab Nr. & Description \\
\hline \multicolumn{2}{|c|}{ Samples from Weinviertel } \\
\hline 15692 & Obersulz: clay plaster + straw \\
\hline 15695 & Obersulz: earth lump \\
\hline 15698 & Obersulz: adobe brick \\
\hline 15699 & Obersulz: clay plaster \\
\hline 14924 & Niedersulz: loess \\
\hline 14925 & Erdpress: loess \\
\hline 15111 & Niedersulz: Tertiary clay \\
\hline 17769 & Ronthal: adobe brick \\
\hline 20032 & Ronthal: clay plaster \\
\hline 20034 & Ronthal: clay plaster \\
\hline 17761 & Ronthal: weathered loess \\
\hline 17763 & Oberdürnbach: colluvium \\
\hline 17442 & Großriedental: adobe brick \\
\hline 17443 & Großriedental: cob wall \\
\hline 17447 & Großriedental: clay plaster \\
\hline 17449 & Großriedental: loess \\
\hline \multicolumn{2}{|c|}{ Samples from Burgenland } \\
\hline 19591 & Heiligenbrunn: earth lump + straw \\
\hline 19592 & Csaterberg: rammed earth \\
\hline \multicolumn{2}{|c|}{ Samples from Hungary } \\
\hline 19593 & Jak Hungary: clay plaster + engobe \\
\hline 19865 & Jak Hungary, engobe gray \\
\hline 19866 & Jak Hungary, Weissig \\
\hline
\end{tabular}

\subsubsection{Research Sites in the Weinviertel}

Obersulz: Four samples originating from a wine press house were used. The press house was dated by dendrochronology to between 1682 and 1733 [6,25] (Figure 3). Ursula Ecker examined the samples as part of her master's thesis at the University of Natural Resources and Life Sciences; her thesis contains the results of her research [26]. Sample 15692 originated from a clay plaster, mixed with beard and husk from grains, used on earth lumps; sample 15695 originated from an earth lump (locally known as "Lehmwuzel"); sample 15698 originated from an adobe brick; and sample 15699 originated from a clay plaster used on clay bricks.

Niedersulz: Sample 14924 originated from excavated loess from the building site of the gate house of the open-air museum; sample 15111 originated from a Tertiary geological layer below the loess. The analytical results come from Rauter and Schößwendtner's bachelor's thesis (2015) [27] at the University of Natural Resources and Life Sciences (like the sample from Erdpress).

Erdpress: Sample 14925 originated from a loess scarp.

Großriedenthal: Four samples were collected in the oldest farmhouse in the village (the farmhouse has since been torn down). Simon Lerch examined them as part of his bachelor's thesis at the University of Natural Resources and Life Sciences, and the thesis contains the results of his research [15] (Figure 4). Sample 17442 originated from an adobe brick, sample 17443 originated from a cob wall, sample 17447 originated from clay plaster, and sample 17449 is locally-available loess. 


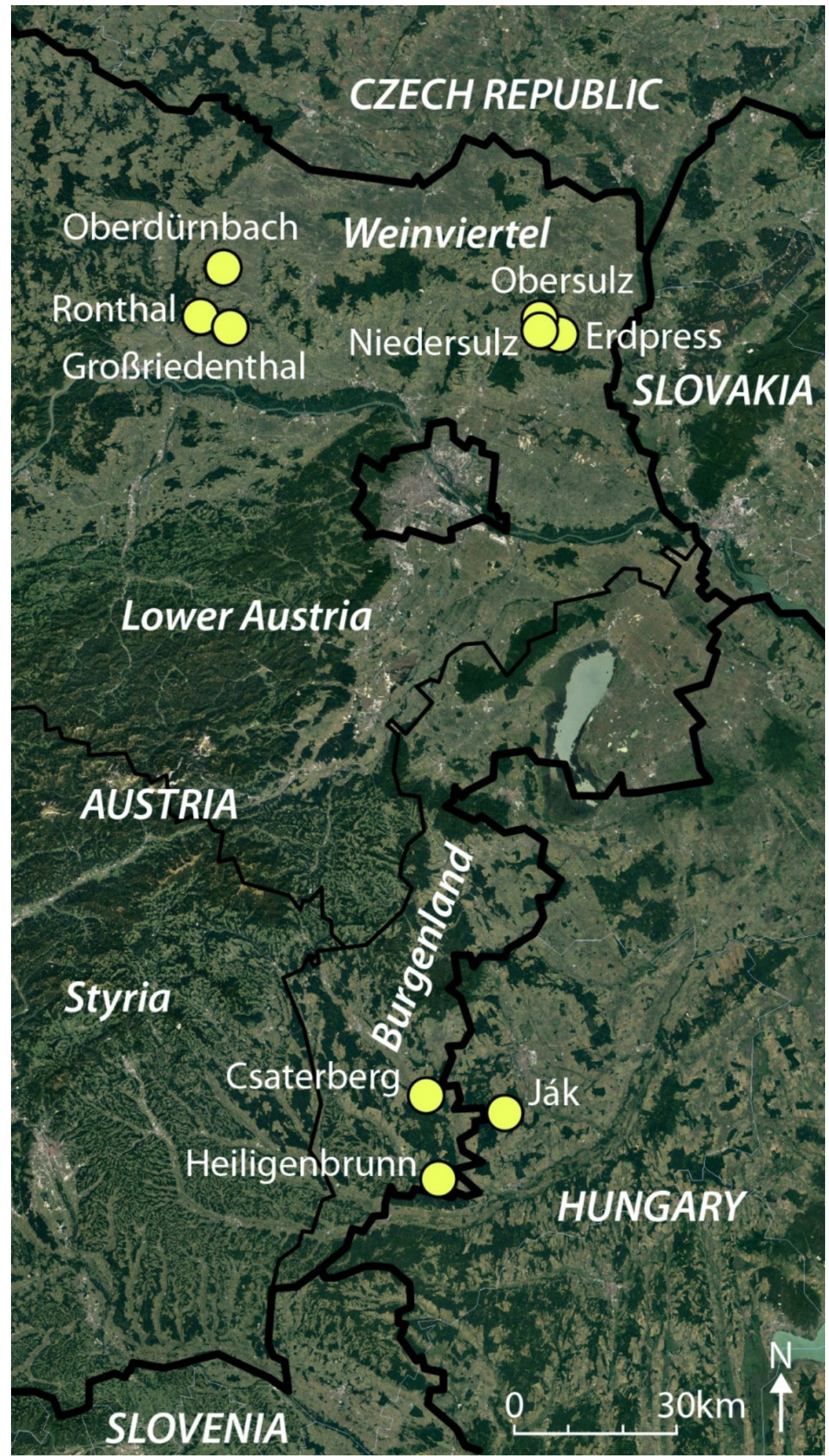

Figure 2. Sampling sites in Weinviertel, Burgenland and Hungary. (Image source: (C) Hubert Feiglstorfer; the map is based on Google Earth 2021 Image Landsat/Copernicus). 


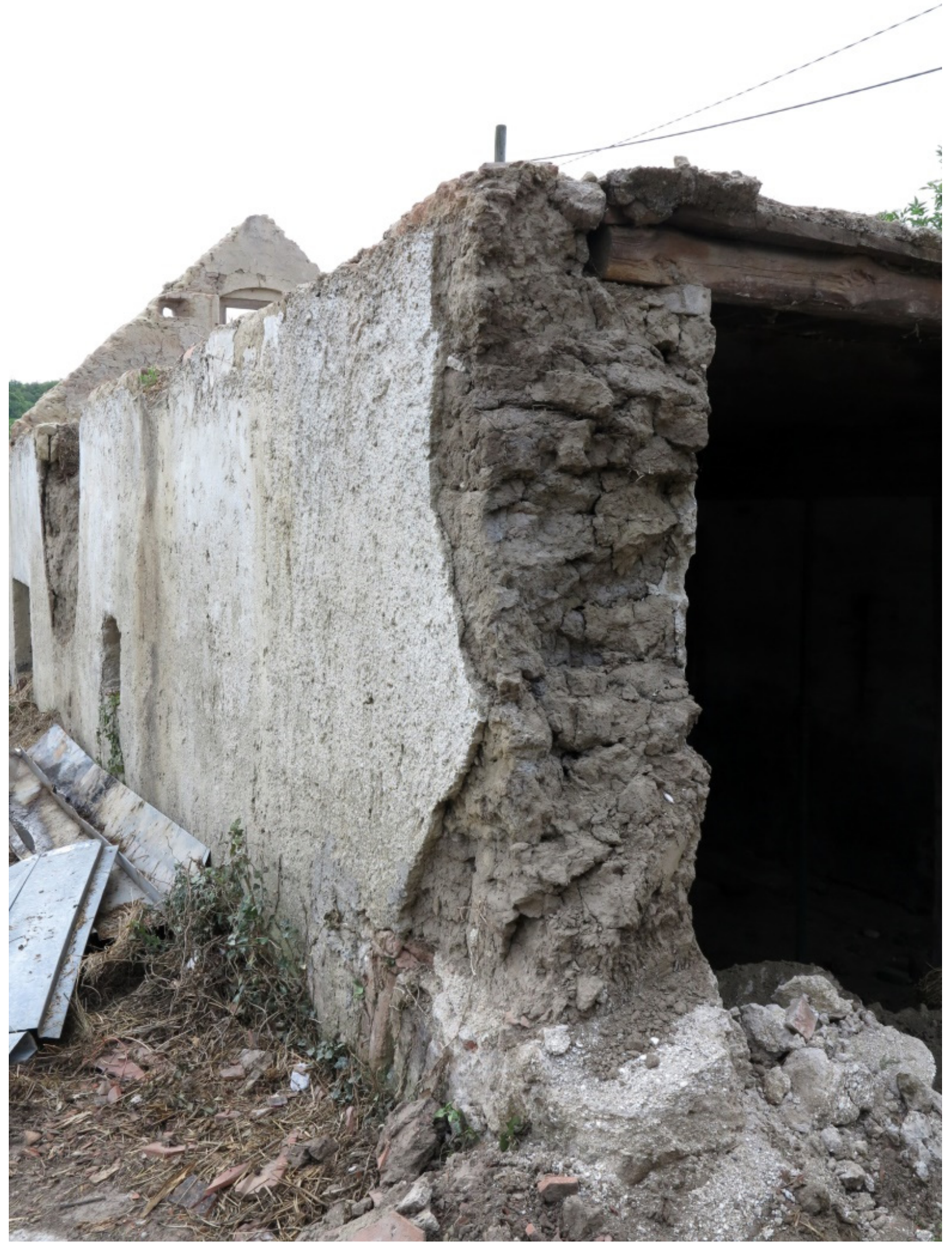

Figure 3. Wall made of earth lumps, locally known as "Lehmwuzel", from Obersulz in Lower Austria (image source: (c) Hubert Feiglstorfer).

Oberdürnbach: Sample 17763 is a sediment which was collected locally. 
Ronthal: Sample 17769 originate from a clay brick from an old farmhouse, sample 20032 originated from a mortar which was also used for plaster for a farm building, sample 20034 originated from the plaster of an exterior wall of a wine cellar, and sample 17761 is weathered loess from a local clay pit. The analytical results for the samples from Oberdürnbach and Ronthal came from the bachelor's thesis written by Grüner and Horvath 2019 [28].

\subsubsection{Research Sites in Burgenland and Western Hungary}

Heiligenbrunn: Sample 19591 originated from an earth lump of a ruin of a wine cellar in the so-called "Kellergasse" (cellar lane) of Heiligenbrunn. The earth lump is mixed with straw (Figure 5).

Csaterberg: Sample 19592 originated from pieces of a ruinous rammed-earth wall, which fell out of the wall and were collected from the ground (Figure 6). The rammed earth was not mixed with organic fibres (Figure 7).

Ják: Sample 19593 originated from the upper clay layer of a wattle and daub construction from the rear part of a farm house. It is mixed with pieces of chopped straw, covered with a layer of a fine clay slurry, and finished with several layers of lime wash. Sample 19865 originated from the bluish-grey engobe on the upper clay layer of sample 19593, and sample 19866 originated from the whitewash covering the blueish-grey engobe layer, and was also from sample 19593 (Figure 8).

\subsection{Methods}

\subsubsection{Particle-Size Distribution}

The particle size analysis was carried out in combination with the clay mineral analysis. The coarse parts of the samples were fractionated using sieves with mesh sizes ranging from 2000 to $20 \mu \mathrm{m}$. The fine particles were analyzed by means of sedimentation analysis with a Sedigraph III 5120 (Micromeritics, Norcross, GA, USA). The grain sizes were quantitatively defined into four fractions: gravel, sand, silt, and clay; and each fraction was again separated into a course, medium and fine fraction.

\subsubsection{Mineralogical Composition by XRD Methods}

The samples were studied by means of X-ray diffraction (XRD). Bulk samples as well as clay fractions $(<2 \mu \mathrm{m})$ were analysed. The samples were studied by means of X-ray diffraction $(X R D)$ using a Panalytical $X^{\prime}$ Pert Pro MPD diffractometer with an automatic divergent slit, $\mathrm{Cu} \mathrm{LFF}$ tube $45 \mathrm{kV}, 40 \mathrm{~mA}$, with an $\mathrm{X}^{\prime}$ Celerator detector. The measuring time was $25 \mathrm{~s}$ per step, with a step size of $0.017^{\circ}$.

The semiquantitative mineral composition of the bulk samples was estimated using Rietveld refinement and the Panalytical software X'Pert HighScore Plus. The carbonate content was additionally determined using thermogravimetric measurements.

The amount of smectite in the bulk sample (effective smectite) was estimated by multiplying the smectite content in the clay fraction by the amount of the clay fraction. Smectite is only present in the clay fraction because of its small crystal size.

The sample preparation for the clay mineral analysis generally followed the methods described by Whittig (1965) [29] and Tributh (1989) [30]. The clay minerals were identified according to Thorez (1975) [31], Brindley and Brown (1980) [32], Moore and Reynolds (1997) [33], and Wilson (1989) [34]. Semiquantitative estimations were carried out using the corrected intensities of characteristic X-ray peaks [35]. The analytical results were assembled in order to search for a relationship between the geological and constructive properties. Finally, these results were compared with each other, sample-wise and region-wise. 


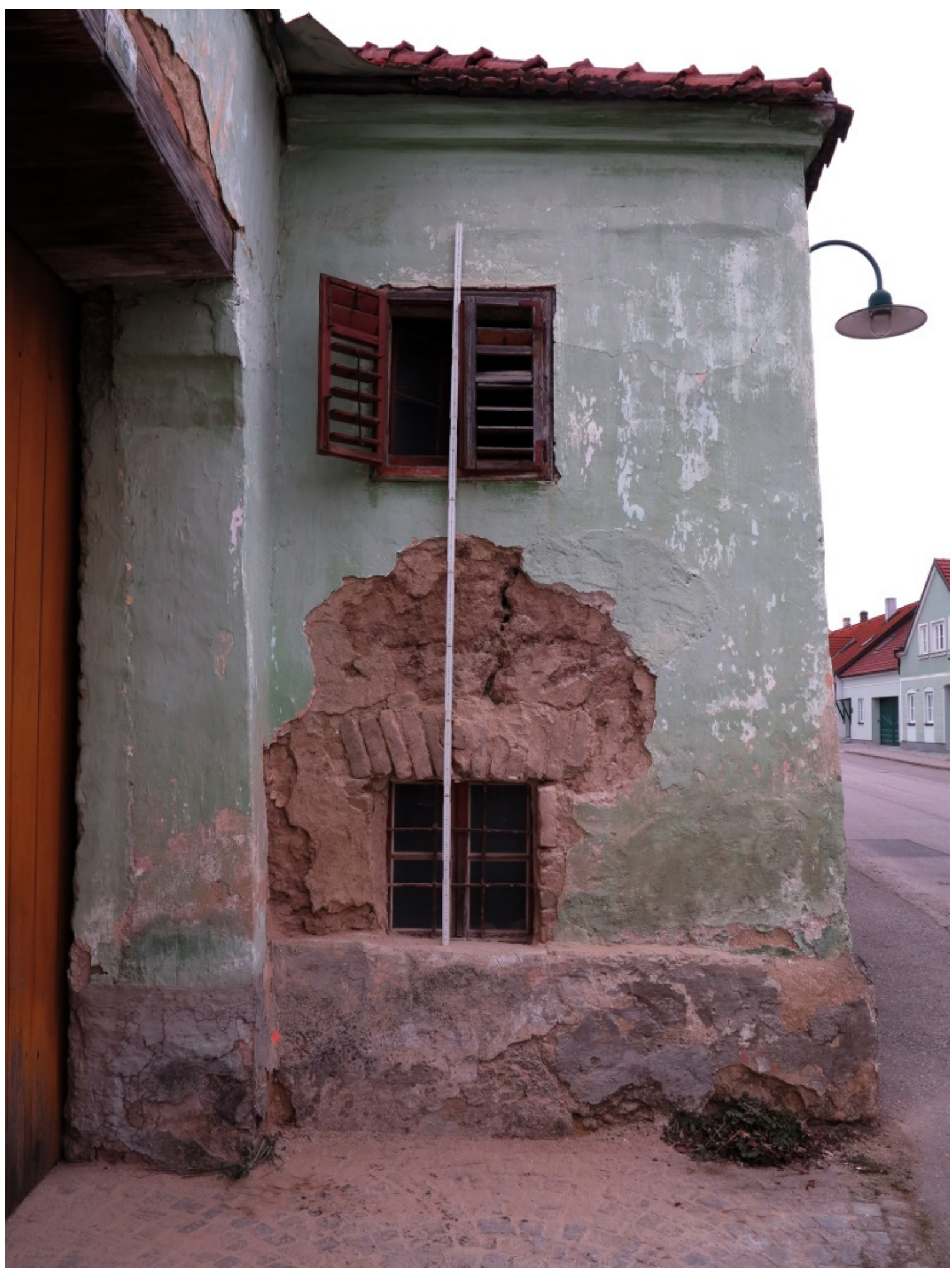

Figure 4. Farm house made of a variety of earth-building techniques, located in Großriedenthal in Lower Austria (Image source: @ Hubert Feiglstorfer). 


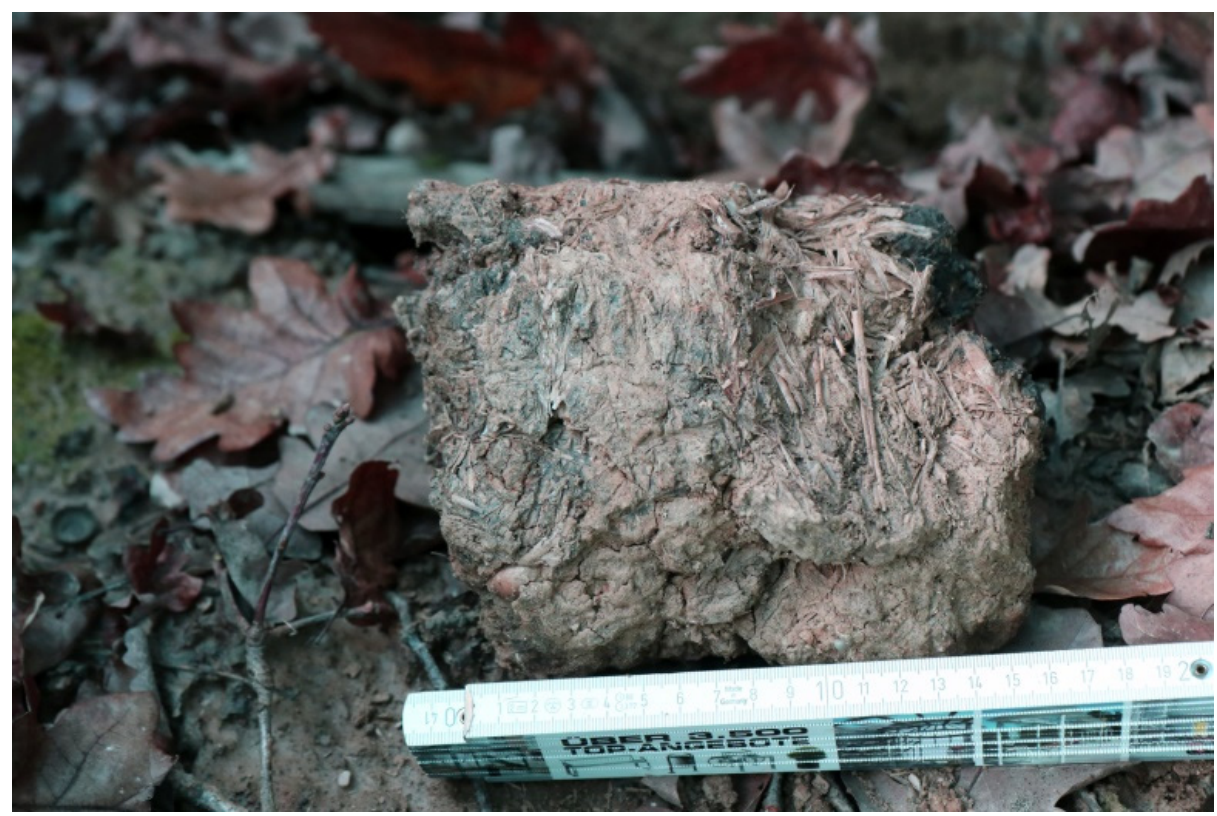

Figure 5. Earth lump ("Lehmwuzel") from a wine press house in Heiligenbrunn in Burgenland (image source: (c) Hubert Feiglstorfer).

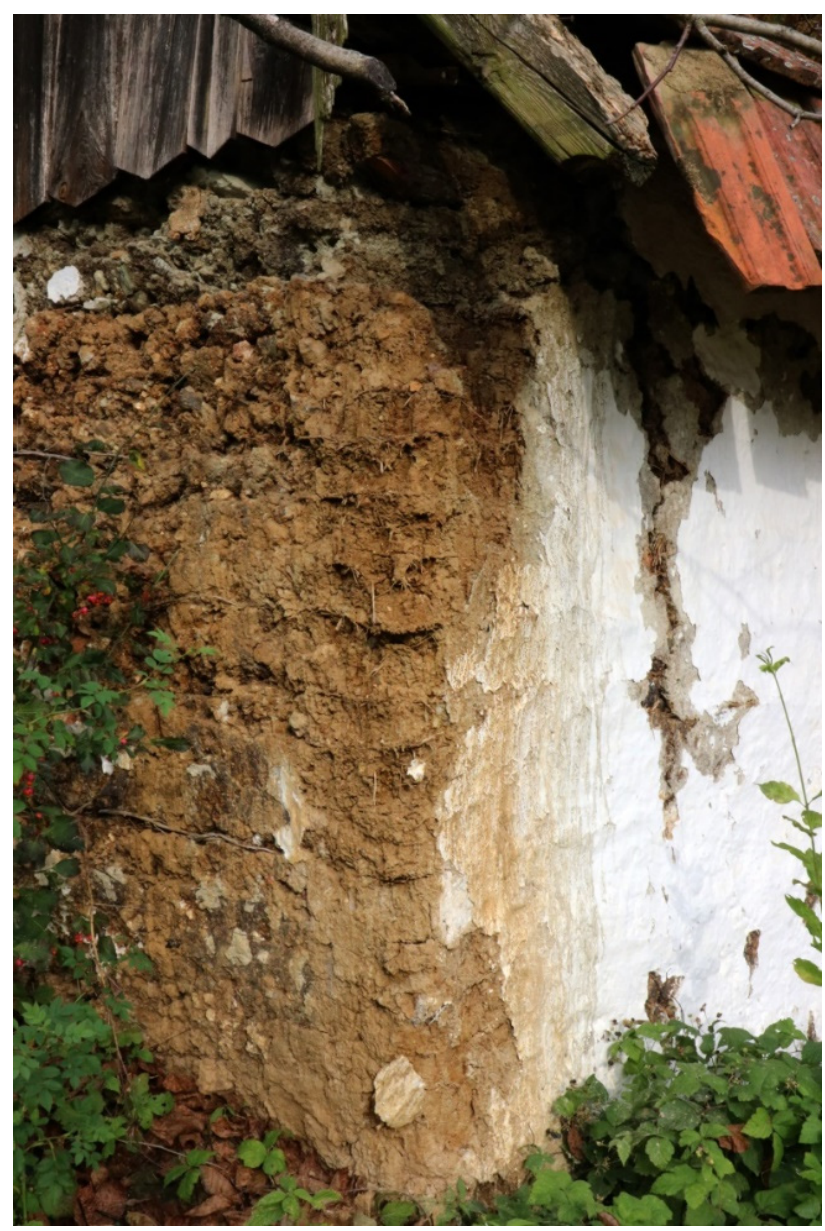

Figure 6. Rammed-earth wall of a wine press house (locally known as "Kellerstöckl") in Csaterberg, Burgenland (image source: (c) Hubert Feiglstorfer). 


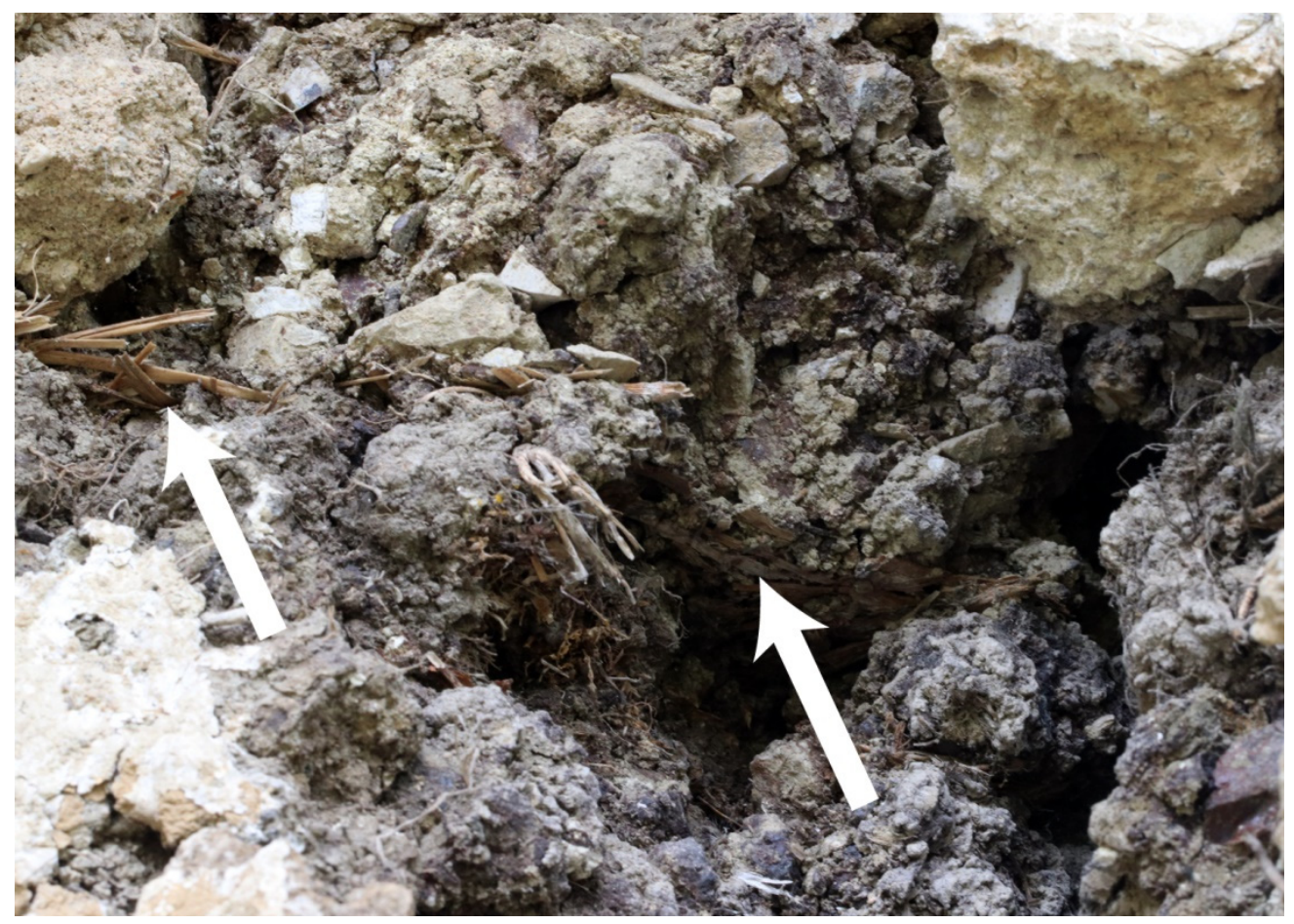

Figure 7. Layers of straw between the individual rammed-earth layers at a wine press house ("Kellerstöckl") in Csaterberg, Burgenland (image source: (c) Hubert Feiglstorfer).

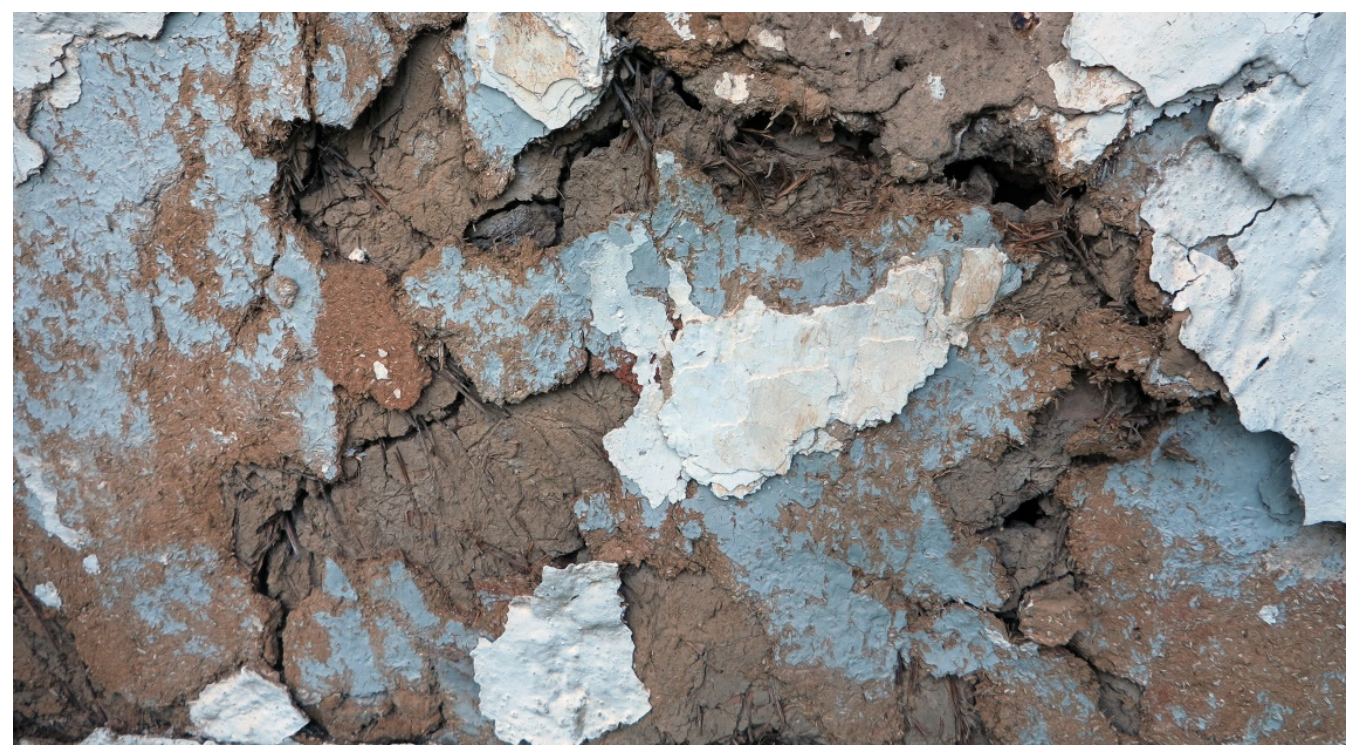

Figure 8. Clay slurry and lime wash on top of a layer of clay from the wattle and daub wall of a farmhouse in Ják, Hungary (image source: () Hubert Feiglstorfer).

\section{Results}

\subsection{Obersulz}

Grain-size Distribution (Table 2).

The average content is as follows: clay, between $17.3 \%$ and $22.8 \%$; silt, between $64.8 \%$ and $70.1 \%$; sand, between $11.1 \%$ and $16.8 \%$; gravel, between $0.1 \%$ and $1.5 \%$. The median is between $19 \mu \mathrm{m}$ and $23 \mu \mathrm{m}$.

Bulk and Clay Mineral Analysis (Tables 3 and 4). 
Table 2. Grain-size distribution. The values are given in mass \%.

\begin{tabular}{|c|c|c|c|c|c|c|}
\hline Lab Nr. & Description & Gravel & Sand & Silt & Clay & Median $[\mu \mathrm{m}]$ \\
\hline 15692 & Obersulz: clay plaster + straw & 1.5 & 11.1 & 70.1 & 17.3 & 20 \\
\hline 15695 & Obersulz: earth lump & 0.1 & 11.0 & 66.1 & 22.8 & 19 \\
\hline 15698 & Obersulz: adobe brick & 0.3 & 13.2 & 69.0 & 17.5 & 21 \\
\hline 15699 & Obersulz: clay plaster & 0.5 & 16.8 & 64.8 & 17.9 & 23 \\
\hline 14924 & Niedersulz: loess & 8.6 & 13.3 & 62.9 & 15.2 & 28 \\
\hline 14925 & Erdpress: loess & 0 & 8.7 & 79.6 & 11.7 & 27 \\
\hline 15111 & Niedersulz: tertiary clay & 0 & 1.6 & 57.4 & 41.0 & 3.3 \\
\hline 17769 & Ronthal: adobe brick & 0.9 & 19.9 & 63.0 & 16.2 & 22 \\
\hline 20032 & Ronthal: clay plaster & 2.3 & 21.7 & 52.8 & 13.2 & 30 \\
\hline 20034 & Ronthal: clay plaster & 2.3 & 28.1 & 55.2 & 14.3 & 30 \\
\hline 17761 & Ronthal: weathered loess & 2.6 & 36.0 & 44.6 & 16.8 & 30 \\
\hline 17763 & Oberdürnbach: colluvium & 15.1 & 54.8 & 24.9 & 5.1 & 160 \\
\hline 17442 & Großriedental: adobe brick & 0.5 & 27.1 & 56.6 & 15.8 & 21.5 \\
\hline 17443 & Großriedental: cob wall & 2.0 & 12.7 & 66.8 & 18.5 & 15.6 \\
\hline 17447 & Großriedental: clay plaster & 0.2 & 10.7 & 73.9 & 15.2 & 13.0 \\
\hline 17449 & Großriedental: loess & 0 & 10.5 & 72.8 & 16.7 & 13.6 \\
\hline 19591 & Heiligenbrunn: earth lump + straw & 2.2 & 29.8 & 38.5 & 29.6 & 11 \\
\hline 19592 & Csaterberg: rammed-earth & 25.5 & 23.6 & 33.4 & 17.6 & 60 \\
\hline 19593 & Jak Hungary: clay plaster + engobe & 5.8 & 13.5 & 58.9 & 21.8 & 13 \\
\hline
\end{tabular}

Table 3. Bulk mineral analysis. The values are given in mass $\%$.

\begin{tabular}{|c|c|c|c|c|c|c|c|c|c|c|c|}
\hline Lab Nr. & Description & 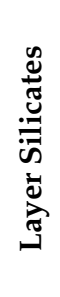 & 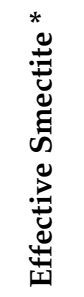 & 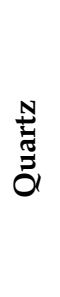 & 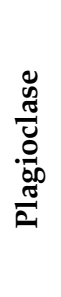 & $\begin{array}{l}\frac{\pi}{\sigma} \\
\frac{o}{0} \\
\frac{0}{0} \\
\frac{1}{\dot{v}}\end{array}$ & $\begin{array}{l}\frac{\mathscr{\theta}}{0} \\
\frac{0}{Z} \\
\frac{0}{2} \\
\frac{Z}{Z}\end{array}$ & 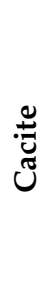 & $\begin{array}{l}\stackrel{0}{*} \\
\stackrel{0}{0} \\
\stackrel{0}{\circ}\end{array}$ & 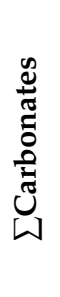 & 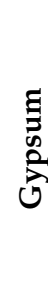 \\
\hline 15692 & Obersulz: clay plaster + straw & 20 & 5.0 & 40 & 11 & 6 & $\mathrm{Sp}$ & 10 & 13 & 23 & - \\
\hline 15695 & Obersulz: earth lump & 15 & 7.3 & 41 & 13 & 5 & 1 & 13 & 12 & 25 & - \\
\hline 15698 & Obersulz: adobe brick & 23 & 6.8 & 40 & 11 & 6 & $\mathrm{Sp}$ & 9 & 11 & 20 & - \\
\hline 15699 & Obersulz: clay plaster & 21 & 6.6 & 40 & 12 & 5 & 1 & 7 & 14 & 21 & - \\
\hline 14924 & Niedersulz: loess & 17 & 5.2 & 43 & 12 & 8 & 1 & 7 & 12 & 19 & \\
\hline 14925 & Erdpress: loess & 16 & 3.4 & 45 & 13 & 7 & 1 & 7 & 11 & 18 & \\
\hline 15111 & Niedersulz: tertiary clay & 50 & 29.5 & 25 & 4 & 3 & - & 9 & 9 & 18 & \\
\hline 17769 & Ronthal: adobe brick & 13 & 3.2 & 35 & 21 & 11 & 2 & 8 & 10 & 18 & - \\
\hline
\end{tabular}


Table 3. Cont.

\begin{tabular}{|c|c|c|c|c|c|c|c|c|c|c|c|}
\hline Lab Nr. & Description & 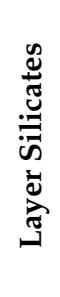 & 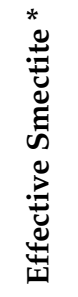 & 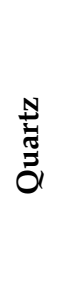 & 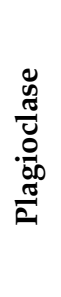 & 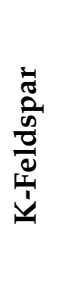 & 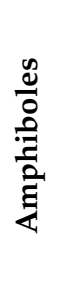 & نัّ & $\begin{array}{l}\stackrel{0}{*} \\
\stackrel{0}{0} \\
\stackrel{0}{0}\end{array}$ & 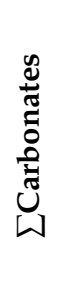 & ह \\
\hline 20032 & Ronthal: clay plaster & 18 & 3.2 & 34 & 18 & 10 & 1 & 9 & 10 & 19 & \\
\hline 20034 & Ronthal: clay plaster & 14 & 3.3 & 36 & 21 & 11 & 2 & 7 & 9 & 16 & \\
\hline 17761 & Ronthal: weathered loess & 12 & 2.5 & 40 & 33 & 15 & - & - & - & - & - \\
\hline 17763 & Oberdürnbach: colluvium & 3 & 1.8 & 24 & 24 & 14 & - & 35 & - & 35 & - \\
\hline 17442 & Großriedental: adobe brick & 14 & 2.4 & 45 & 16 & 6 & 1 & 11 & 7 & 18 & - \\
\hline 17443 & Großriedental: cob wall & 12 & 2.4 & 39 & 12 & 8 & 1 & 13 & 15 & 28 & - \\
\hline 17447 & Großriedental: clay plaster & 15 & 2.7 & 38 & 12 & 9 & 1 & 11 & 11 & 22 & - \\
\hline 17449 & Großriedental: loess & 17 & 2.3 & 40 & 18 & 6 & 3 & 5 & 11 & 17 & - \\
\hline 19591 & Heiligenbrunn: earth lump + straw & 42 & 15.4 & 46 & 9 & 3 & - & - & - & - & - \\
\hline 19592 & Csaterberg: rammed-earth & 52 & 14.1 & 30 & 13 & 5 & - & - & - & - & - \\
\hline 19593 & Jak Hungary: clay plaster + engobe & 29 & 2.6 & 48 & 16 & 6 & - & - & - & - & 1 \\
\hline 19865 & Jak Hungary, engobe gray & 56 & $\mathrm{~nm}$ & 25 & 8 & 10 & - & - & - & - & 1 \\
\hline 19866 & Jak Hungary, Weissig & 1 & 0 & 1 & - & - & - & 96 & - & 96 & 2 \\
\hline
\end{tabular}

${ }^{*}$ Effective smectite $=$ the content of smectite in the $2 \mu$ fraction multiplied by the amount of the clay fraction. $\mathrm{nm}=$ not measured .

Table 4. Clay mineral analysis. The values are given in mass \%.

\begin{tabular}{|c|c|c|c|c|c|c|c|}
\hline \multirow{2}{*}{ Lab No } & \multirow{2}{*}{ Description } & \multirow{2}{*}{$\begin{array}{l}\text { Smec- } \\
\text { Tite }\end{array}$} & \multirow{2}{*}{ Illite } & \multirow{2}{*}{ Kaolinite } & \multicolumn{2}{|c|}{ Chlorite } & \multirow{2}{*}{ Mixed Layer } \\
\hline & & & & & Prim. & Sec. & \\
\hline 15692 & Obersulz: clay plaster + straw & 29 & 30 & 21 & 20 & - & - \\
\hline 15695 & Obersulz: earth lump & 32 & 32 & 17 & 19 & - & - \\
\hline 15698 & Obersulz: adobe brick & 39 & 22 & 20 & 19 & - & - \\
\hline 15699 & Obersulz: clay plaster & 37 & 27 & 19 & 17 & - & - \\
\hline 14924 & Niedersulz: loess & 34 & 22 & 27 & 17 & - & - \\
\hline 14925 & Erdpress: loess & 29 & 25 & 33 & 13 & - & - \\
\hline 15111 & Niedersulz: tertiary clay & 72 & 19 & 9 & 0 & - & - \\
\hline 17769 & Ronthal: adobe brick & 20 & 29 & 21 & 30 & - & - \\
\hline 20032 & Ronthal: clay plaster & 24 & 31 & 22 & 22 & - & - \\
\hline 20034 & Ronthal: clay plaster & 23 & 31 & 21 & 25 & & \\
\hline 17761 & Ronthal: weathered loess & 15 & 75 & 10 & $\operatorname{tr}$ & - & $\operatorname{tr}$ \\
\hline 17763 & Oberdürnbach: colluvium & 35 & 20 & 45 & $\operatorname{tr}$ & - & - \\
\hline 17442 & Großriedental: adobe brick & 15 & 36 & 22 & 27 & - & - \\
\hline 17443 & Großriedental: cob wall & 13 & 41 & 28 & 18 & - & - \\
\hline 17447 & Großriedental: clay plaster & 18 & 32 & 33 & 17 & - & - \\
\hline
\end{tabular}


Table 4. Cont.

\begin{tabular}{|c|c|c|c|c|c|c|c|}
\hline \multirow{2}{*}{ Lab No } & \multirow{2}{*}{ Description } & \multirow{2}{*}{$\begin{array}{l}\text { Smec- } \\
\text { Tite }\end{array}$} & \multirow{2}{*}{ Illite } & \multirow{2}{*}{ Kaolinite } & \multicolumn{2}{|c|}{ Chlorite } & \multirow{2}{*}{ Mixed Layer } \\
\hline & & & & & Prim. & Sec. & \\
\hline 17449 & Großriedental: loess & 14 & 21 & 21 & 43 & - & - \\
\hline 19591 & Heiligenbrunn: earth lump + straw & 52 & 23 & 25 & $\operatorname{tr}$ & - & $\operatorname{tr}$ \\
\hline 19592 & Csaterberg: rammed-earth & 80 & 17 & 1 & 2 & - & - \\
\hline 19593 & Jak Hungary: clay plaster + engobe & 12 & 56 & 18 & - & 14 & - \\
\hline
\end{tabular}

The average mineral content of the samples is as follows: quartz, around $40 \%$; potash feldspar, around $6 \%$; phyllosilicates, i.e., mica and clay minerals, between $15 \%$ and $23 \%$; carbonates, between $20 \%$ and $25 \%$.

The content of smectite in the clay fraction $<2 \mu \mathrm{m}$ is between $29 \%$ and $39 \%$, the content of illite (the weathering product of micas) is between $22 \%$ and $32 \%$, and the content of kaolinite is between $17 \%$ and $21 \%$.

4.2. Niedersulz and Erdpress

Grain-size Distribution (Table 2, Figure 9).

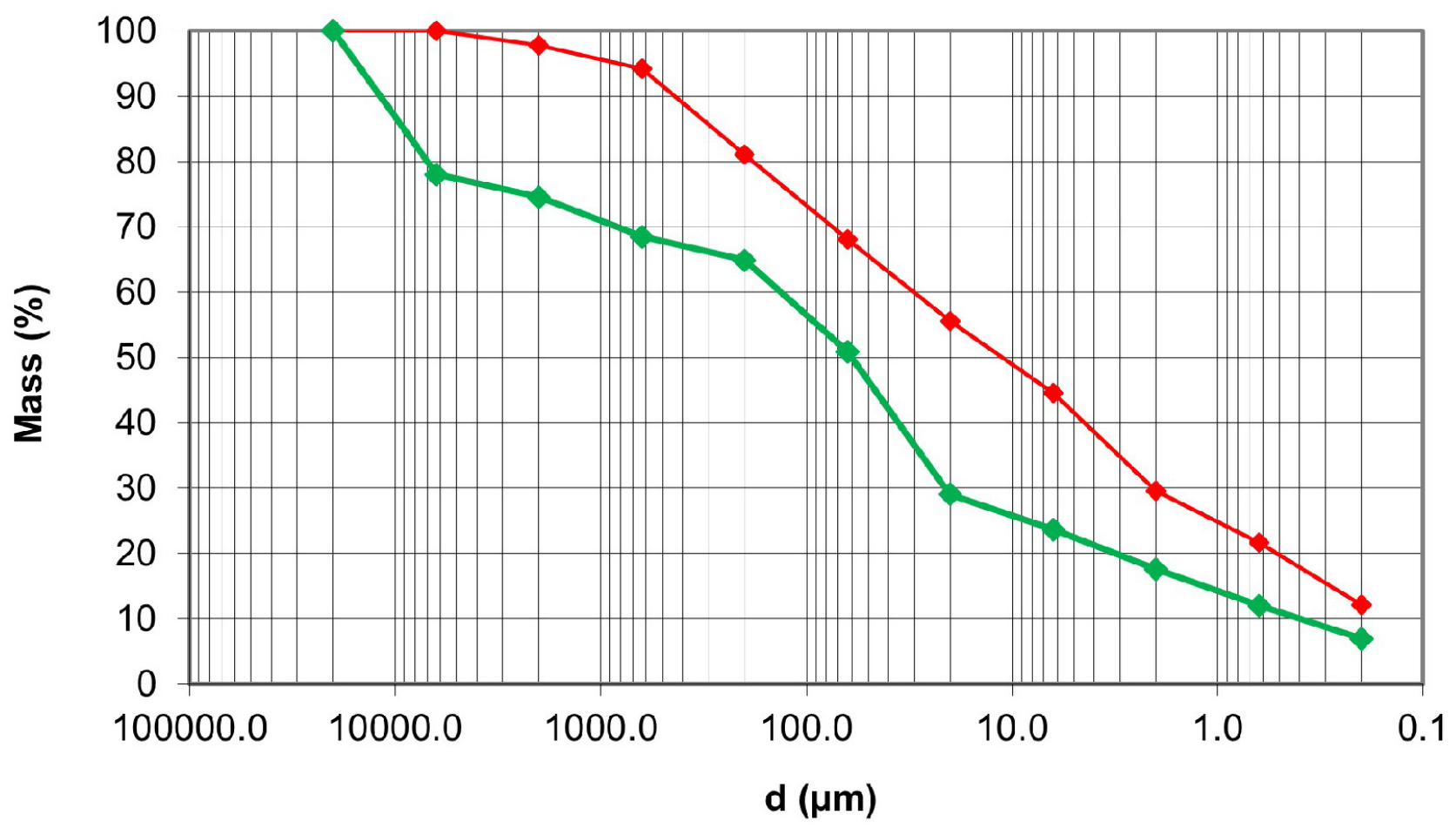

Figure 9. Cumulative curves from the grain-size distributions: red curve = loess from Erdpress, green curve = clay from a rammed-earth wall in Csaterberg.

The clay contents of $15.2 \%$ (Niedersulz loess, sample 14924) and 11.7\% (Erdpress loess, sample 14925) are similar to those of the Obersulz samples, as is the silt content, at $62.9 \%$ (Niedersulz loess) and 79.6\% (Erdpress loess), and the sand content, at 13.3\% (Niedersulz loess) and $8.7 \%$ (Erdpress loess). The Tertiary clay from sample 15111 differs strongly from the above-listed values with a much higher clay content $(41 \%)$ and a lower content of silt $(57.4 \%)$ and sand (1.6\%). Accordingly, its median of $3.3 \%$ is comparatively low.

Bulk and clay mineral analysis (Tables 3 and 4, Figures 10 and 11).

The samples 14924 (Niedersulz loess) and 14925 (Erdpress loess) show a similar quartz content, ranging from around $43 \%$ to $45 \%$, a potash feldspar content of around $8 \%$, a phyllosilicate content of around $17 \%$, and a carbonate content of around $19 \%$. The Tertiary 
clay sample (15111) differs strongly, with a comparatively low content of quartz (25\%) and potash feldspar (3\%), and a high content of phyllosilicates (50\%), while the content of carbonates is similar to the content given for the samples from Niedersulz and Erdpress which were described above.

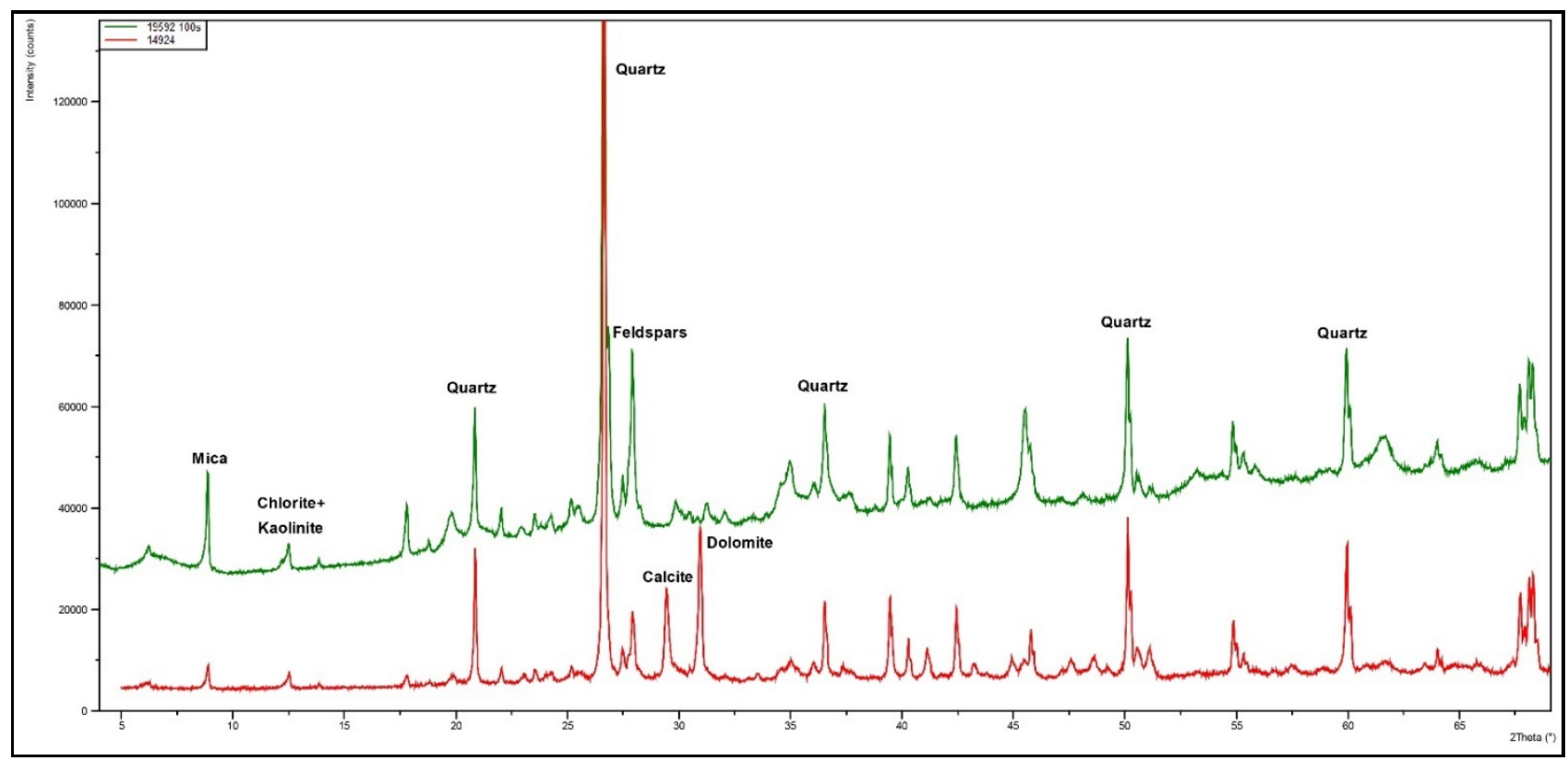

Figure 10. Diffractograms from bulk samples: red curve = loess from Niedersulz, green curve = clay from a rammed-earth wall in Csaterberg.

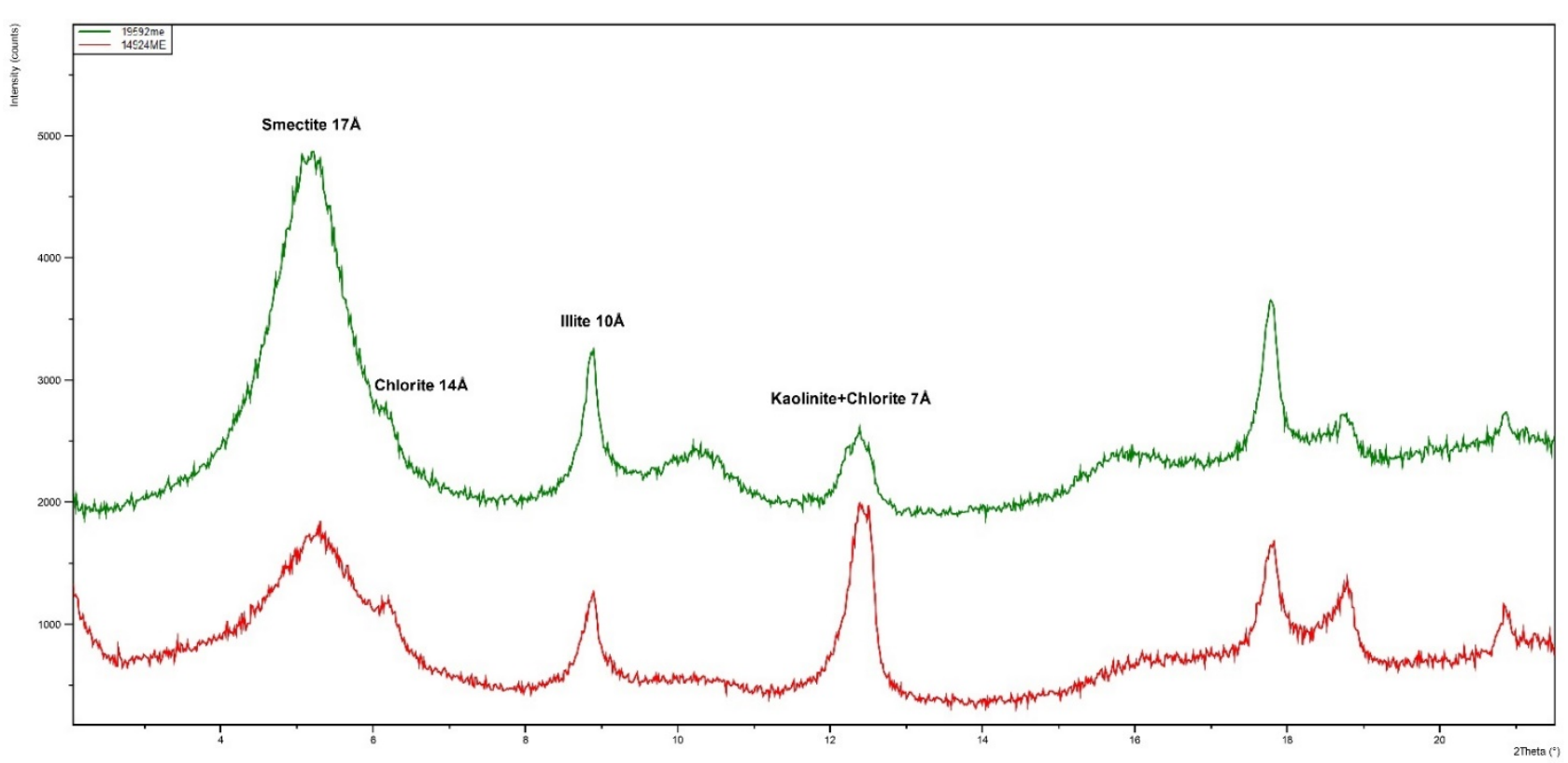

Figure 11. Diffractograms from clay fractions: red curve = loess from Niedersulz, green curve = clay from a rammed-earth wall in Csaterberg. The samples are saturated and glycolated magnesium.

Samples 14924 (Niedersulz loess) and 14925 (Erdpress loess) show similar amounts of different types of clay minerals compared to the Obersulz samples, while the Tertiary clay sample (15111) differs strongly, with a comparatively high smectite content $(72 \%)$ and a low content of illite $(19 \%)$ and kaolinite $(9 \%)$. 


\subsection{Großriedenthal}

Grain-size Distribution (Table 2).

The grain size distribution and the median of the Großriedenthal samples are similar to those for the Obersulz, Niedersulz and Erdpress loess samples, with the exception of the adobe brick, which has a slightly lower silt content of $56.6 \%$ and a slightly higher sand content of $27.1 \%$. The medians of the samples of the cob wall $(15.6 \mu \mathrm{m})$, plaster $(13 \mu \mathrm{m})$ and raw material $(13.6 \mu \mathrm{m})$ are the lowest among the Weinviertel loess samples.

Bulk and Clay Mineral Analysis (Tables 3 and 4).

The samples show a rather similar bulk mineralogy to the loess samples from Obersulz, Niedersulz and Erdpress.

The content of the clay minerals is close to those of the Obersulz, Niedersulz and Erdpress loess samples, with only the content of smectite being lower, ranging from $13 \%$ to $18 \%$.

\subsection{Oberdürnbach}

Grain-size Distribution (Table 2).

The sediment (sample 17763) differs strongly from the loess samples described before, with a comparatively low content of clay (5.1\%) and silt (24.9\%), a high content of sand $(54.8 \%)$ and gravel $(15.1 \%)$, and a comparatively high median of $160 \mu \mathrm{m}$.

Bulk and Clay Mineral Analysis (Tables 3 and 4).

Here, there is a striking difference from the loess samples from Obersulz, Niedersulz and Erdpress, with a comparatively low content of quartz (24\%) and phyllosilicates (3\%), and a high carbonate content (35\%).

The content of clay minerals is similar to those of the Obersulz, Niedersulz and Erdpress loess samples, differing only by an increased content of kaolinite (45\%).

\subsection{Ronthal}

Grain-size Distribution (Table 2).

The grain-size distribution and the medians of the Ronthal samples differ slightly from those of the Obersulz, Niedersulz and Erdpress loess samples, according to a slightly lower content of clay and silt, and a slightly higher content of sand and gravel. Only the Ronthal loess sample shows a distinctly lower silt content (44.6\%) and a higher content of sand $(36 \%)$.

Bulk and Clay Mineral Analysis (Tables 3 and 4).

The samples have a rather similar bulk mineralogy, although in comparison with the loess samples from Obersulz, Niedersulz and Erdpress, the content of potash feldspar is higher (ranging from 10\% to $15 \%$ ), as is the content of plagioclase (ranging from 18\% to $33 \%$ ).

The clay mineral content in the clay fraction $(<2 \mu \mathrm{m})$ differs from the Obersulz, Niedersulz and Erdpress loess samples, having a lower content of smectite (20\%-23\%). In particular, sample 17761 differs markedly, with a lower content of smectite $(15 \%)$ and kaolinite $(10 \%)$, and a high content of illite $(75 \%)$.

\subsection{Heiligenbrunn}

Grain-size Distribution (Table 2).

The clay content of sample 19591 is $29.6 \%$, with a fine clay content of $12.1 \%$, a mediumsize clay content of $9.5 \%$, and a coarse clay content of $7.9 \%$. The silt content is $38.5 \%$, with a rather similar distribution among fine, medium-size and coarse silt. Although the sand content of $29.7 \%$ is similar to the clay content, it stands out for having fewer coarse fractions, i.e., $3.7 \%$ coarse sand and $2.2 \%$ fine gravel, with the latter reaching a size of not more than $6.3 \mathrm{~mm}$. The median of this sample is around $11 \mu \mathrm{m}$.

Bulk and Clay Mineral Analysis (Tables 3 and 4). 
The sample has an average content of quartz (46\%), a low content of potash feldspar (3\%), a comparatively high phyllosilicate content (42\%), and no carbonates. As for the clay minerals, the sample contains a high amount of smectite (52\%), 23\% illite and 25\% kaolinite.

\subsection{Csaterberg}

Grain-size Distribution (Table 2, Figure 9).

The clay content in sample 19592 is $17.6 \%$, with a rather homogenous distribution of fine, medium size and coarse clay. The silt content is $33.4 \%$, and the most prominent silt fraction in this sample is coarse silt, at $21.9 \%$. The sand content is $23.6 \%$, and the gravel content is $25.5 \%$. Its rather coarse appearance, reflecting its total of $49.2 \%$ sand and gravel, is distinctive for this sample. The median for this sample is around $60 \mu \mathrm{m}$ (Figure 8).

Bulk and Clay Mineral Analysis (Tables 3 and 4, Figures 10 and 11).

The sample has an average content of quartz (30\%) and potash feldspar (5\%), a comparatively high phyllosilicate content (52\%), and no carbonates (Figure 9). This rammed-earth sample includes large pieces of opal and serpentine gravel.

As for the clay minerals, the sample contains a very high amount of smectite in the clay fraction of $<2 \mu \mathrm{m}(80 \%), 17 \%$ illite, and the lowest content of kaolinite $(1 \%)$ and chlorite $(2 \%)$ of all of the samples analysed (Figure 10).

\subsection{Ják}

Grain-size Distribution.

The clay content of sample 19593 stands at $21.8 \%$. The high fraction of silt $(58.9 \%)$ is distinctive for this sample, while the content of sand $(13.5 \%$, with $9.1 \%$ consisting of fine sand) and the gravel content of $5.8 \%$ point to a low content of coarse material. The median of this sample is about $10.4 \mu \mathrm{m}$.

Bulk and Clay Mineral Analysis.

Sample 19593, from the upper clay layer, consists of $48 \%$ quartz, and has an average content of potash feldspar (6\%) and a comparatively high content of phyllosilicates (29\%), no carbonates, and 1\% gypsum. Sample 19865-from the engobe layer-is different, with a much lower quartz content (25\%) and a much higher phyllosilicate content $(56 \%)$. Sample 19866, from the whitewash layer, has an extremely low content of phyllosilicates (1\%) and of quartz (1\%), a high content of carbonates (96\%), and only a small amount of gypsum (2\%). As for the clay minerals, sample 19593 contains a moderate amount of smectite (12\%), kaolinite (18\%) and illite (56\%), and only a small amount of chlorite (14\%).

\section{Discussion}

The merging of the investigation data by object and by location gives us a new picture of clay as a building material in the Weinviertel and Burgenland regions, and in Western Hungary. The following section first presents the analysis data location by location, discussing it within the individual regions of Weinviertel, Burgenland and Western Hungary, and subsequently uses a comparative approach to build up a bigger picture.

\subsection{Geology and Grain-Size Distribution}

In the Weinviertel, silt is the predominant grain-size fraction, with amounts of up to $79.6 \%$. The sand content is low, and very small amounts of gravel are present. The clay fraction of $<2 \mu \mathrm{m}$ for the loess-based material ranges from $5.1 \%$ to $22.8 \%$. The median of the grain-size distribution is also uniform, with values of between about $20 \mu \mathrm{m}$ and $30 \mu \mathrm{m}$.

The locations of Obersulz, Niedersulz, Erdpress and Großriedenthal are characterized by loess deposits. Sandy and gravelly deposits appear on a small scale, and characterize the local material. This fact results in an average clay content of between $11.7 \%$ and $22.8 \%$, a silt content of between $56.6 \%$ and $79.6 \%$, a sand content of between $8.7 \%$ and $27.1 \%$, and a gravel content of up to $2 \%$. The median is between 13 and $28 \mu \mathrm{m}$. 
The Großriedenthal samples, and in particular the clay plaster and the loess pit samples, represent the finest clays in this summary, and are characterized by a slightly higher proportion of silt and a lower proportion of sand.

From the grain-size distribution, we can see that the material was used for different purposes, whether for earth lumps, bricks or plaster at different processing periods. This is different in Großriedenthal, where the brick clay was mixed with sand. The clay which was used for the cob wall and the clay plaster includes no additives and is similar to the material from the clay pit.

The grain-size distribution of Tertiary clay is quite different, as this is a much older geological layer below the loess. The high clay content of $41 \%$ and the slightly lower silt content, as well as the median of only $3.3 \mu \mathrm{m}$, reveal a very fine material.

Looking at the western edge of the Weinviertel at the foot of the Manhartsberg, the clay appears to be coarser than the eastern loess samples, mainly due to the higher content of gravel and sand and the lower content of silt, which is also reflected by a median of $30 \mu \mathrm{m}$. In Ronthal, the clay with a lower proportion of gravel was used only for bricks, whereas for mortar and plaster, clay with $2.3 \%$ gravel was used. The coarse clay from Oberdürnbach points to the influence of the Bohemian Massif from the west.

The material from Burgenland and Hungary is much more differentiated. The samples contain much coarser elements, with up to $25.5 \%$ gravel in the rammed-earth sample from Csaterberg.

The geology of Southern Burgenland and neighbouring Western Hungary is different to the geology of the Weinviertel. Only the clay from the Western Hungarian loess region is similar to the Weinviertel loess, although it has a slightly lower silt content and a slightly higher clay content, and a higher proportion of gravel. The clay from Heiligenbrunn is different. In an area characterized by clay and sand, it clearly stands out from the loess clay in its much higher proportion of clay, sand and gravel, and its much lower proportion of silt. With its high proportion of gravel, the sample from the serpentine-rich Csaterberg stands out from all of the other samples.

\subsection{Bulk Mineralogy}

The samples from the Weinviertel contain phyllosilicates in proportions ranging between $3 \%$ and $50 \%$, with quartz being dominant in all of the samples, at around $40 \%$. The samples also contain plagioclase feldspars and potash feldspars. The Weinviertel samples are moderately calcareous. Calcite and dolomite in similar amounts are present in all of the samples analysed, with a combined total of up to $35 \%$.

All of the Burgenland samples are free of carbonates. The proportion of phyllosilicates is noticeably higher, at up to $56 \%$. Quartz and potash feldspars are present in high and moderate proportions.

The coarse particles in the rammed-earth sample from Csaterberg consist of opal and serpentine. The samples from Ják revealed small amounts of gypsum.

\subsection{Clay Mineralogy}

The type of clay minerals present in the raw material for clay buildings is of great importance for their quality. Smectite has the best binding power of all of the clay minerals because it consists mostly of very fine-grained particles of less than $0.2 \mu \mathrm{m}$, and therefore its surface area is up to $800 \mathrm{~m}^{2} / \mathrm{g}$ [36] (p. 87). From this follows a very high cohesion, which is responsible for that high binding power.

In the samples from the Weinviertel, amounts between $13 \%$ and $72 \%$ of that important clay mineral are present. Illite is present in a proportion ranging from $19 \%$ to $75 \%$. As for the amounts of kaolinite and chlorite, these are similar in all of the samples.

The qualitative clay mineral composition of all of the samples from the Weinviertel is relatively uniform; the quantitative composition is in the range of the typical loess sediments. 
This is quite a different case with the samples from Burgenland and Hungary. The clay fraction from the rammed-earth sample from Csaterberg consists of 80\% smectite and small amounts of illite, with hardly any kaolinite or chlorite.

The Heiligenbrunn sample also consists of plenty of smectite, illite and kaolinite. Eighty per cent is an extremely high proportion of smectite, which is usually only seen in bentonites. Generally, clay with such a high smectite content is improper for earth-building techniques. However, thanks to the small amount of clay fraction (only $17.6 \%$; see Table 4 ) in this sample, the smectite content in the bulk sample is only around $14 \%$, which is a useful value for rammed-earth construction.

\subsection{Relationship between the Mineralogical Properties of the Clay and the Local Earth-Building Traditions}

The clay in the Weinviertel, Burgenland and Western Hungary is ideal for building purposes, but there are regional differences which had a decisive impact on the type of use it was put to in the cultural and historical development.

Figures 9-11 illustrate the mineralogical differences caused by the respective geological conditions. Regarding the impact of clay minerals on the building technology of vernacular earthen architecture, various geological situations determined a diversity of local earth-building traditions in Eastern Austria. On the one hand, the different grain-size distributions between the fine loess (for example, in Erdpress in the Weinviertel) and the coarse clay (for example, in Csarterberg) have a direct influence on the choice of building techniques and the method of processing (Figure 9). A characteristic difference can also be found in the content of calcite and dolomite when comparing, for example, calcerous loess in Niedersulz and the lime-free clay in examined clays in Southern Burgenland (Figure 10). An important finding is the content of smectite, which acts as an adhesive in the clay construction techniques throughout the entire Eastern Austrian region (Figure 11).

It is striking that earth-lump walls, cob walls and adobe walls can be found throughout Eastern Austria despite the mentioned mineralogical differences between the Weinviertel and Southern Burgenland. Accordingly, the choice of the respective techniques must have had a local cultural and not mainly a mineralogical background. In contrast, due to different geological situations, the technique of ramming was traditionally not used in the Weinviertel, but was used in certain areas of Burgenland.

In the Weinviertel, for example, the sandier clay from Ronthal does not preclude the use of the clay for traditional clay building techniques and we can state that the builders in rural areas were quite flexible, processing clay with different proportions of coarse and fine material. From this point of view, the application of particular earth processing techniques must have been local and culturally predetermined. Even a small amount of gravel was not an obstacle to its use in plastering. It is particularly due to the loess content that the material for the Weinviertel earth-building techniques gained a foothold in the region. In particular, there are certain processing specifics that formed regional typological markers due to the relatively fine material, including, for example, the processing of cob walls without any formwork, and the absence of the rammed-earth technique in the vernacular building history of the Weinviertel.

In comparison, Burgenland shows different results. Despite the high proportion of sand in the clay used for earth lumps in Heiligenbrunn, sand is considered to be difficult to obtain in this area, and needs to be delivered from further away, which is an indication that sand naturally occurs in a form mixed with clay, lime and gravel, but not on its own. The higher proportion of gravel in the Burgenland samples meant that cob walls could not be straightened as easily by being parted with a spade, as they could in the Weinviertel, which might be one of the reasons that, unlike in the Weinviertel, formwork was commonly used for earth walls in Southern Burgenland. Furthermore, because of the high content of smectite, the clay in Csaterberg can easily be processed in a rammed-earth wall despite its high proportion of gravel. However, besides the comparatively high proportion of clay and smectite, the rammed-earth wall had to be reinforced (e.g., with prickly juniper branches), 
and the individual rammed-earth layers had to be kept in shape and free from cracks by inserting straw as a separating layer between the individual rammed-earth layers. For the plaster coatings, a clay slip was used as a surface coating in Heiligenbrunn and Ják, as a layer below the slaked-lime paint. This fact is an indication of the historical use of clay slip as the top layer of plaster before the emergence of the local tradition of using lime for white-washing. The fact that the area around Ják was known for pottery production could underscore the use of slurry in building. Research into a cultural-historical connection in this concern is a future aim.

\section{Conclusions}

The geological situation in the investigated regions of Eastern Austria is favorable for earth-building. Gigantic amounts of Tertiary clays and loess from the Pleistocene are available. In these sediments, the clay mineral smectite-an outstanding binding agent for earth construction-is present. Therefore, this excellent building material could be used for all of the different types of earth-building techniques in Weinviertel, Burgenland and Western Hungary as well. In the geolgical window of Eisenberg, hard rocks like serpentinites are present, and their weathering products are responsible for the coarser sediments in Csaterberg. Sediments with a high amount of gravel were only used for rammed-earth techniques.

Author Contributions: Conceptualization, H.F. and F.O.; methodology, H.F. and F.O.; software,
H.F. and F.O.; validation, H.F. and F.O.; formal analysis, H.F. and F.O.; investigation, H.F. and F.O.;
resources, H.F. and F.O.; data curation, H.F. and F.O.; writing-original draft preparation, H.F. and
F.O.; writing-review and editing, H.F. and F.O.; visualization, H.F. and F.O.; supervision, H.F. and
F.O.; project administration, H.F. and F.O.; funding acquisition, H.F. and F.O. All authors have read
and agreed to the published version of the manuscript.

Funding: The authors are greatful to the Austrian Academy of Sciences for funding the publication of this article.

Data Availability Statement: Not applicable.

Conflicts of Interest: The authors declare no conflict of interest.

\section{References}

1. Minke, G. Das Neue Lehm-Handbuch; Ökobuch: Rastede, Germany, 2001.

2. Feiglstorfer, H. Mineral Building Traditions in the Himalayas. The Mineralogical Impact on the Use of Clay as Building Material; De Gruyter: Berlin, Germany, 2019. [CrossRef]

3. Schauppenlehner, T.; Eder, R.; Ressar, K.; Feiglstorfer, H.; Meingast, R.; Ottner, F. A Citizen Science Approach to Build a Knowledge Base and Cadastre on Earth Buildings in the Weinviertel Region, Austria. Heritage 2021, 4, 7. [CrossRef]

4. Feiglstorfer, H. Lehmbaubestand in Kellergassen. In Kulturlandschaft der Kellergassen. Erforschung Schutz Erhaltung; Gerold, E., Ed.; Verlag Berger: Horn and Wien, Austria, 2020; pp. 107-113.

5. Feiglstorfer, H.; Meingast, R. Historischer Baubestand und Klimaschutz; Denkmalpflege in Niederösterreich. 2019; pp. 16-20. Available online: https://www.noe.gv.at/noe/Kunst-Kultur/Denkmalpflege_Noe.html (accessed on 13 December 2021).

6. Meingast, R.; Feiglstorfer, H. Earth building history in Eastern Austria. In Earth Construction and Tradition; Hubert, F., Ed.; IVA-ICRA Verlag: Vienna, Austria, 2018; Volume 2, pp. 21-83.

7. Feiglstorfer, H.; Meingast, R.; Ottner, F. Lehm und Lehmbau in Weinviertler Kellergassen. Bestand, Erhaltung und Sanierung. In Österreichische Zeitschrift für Kunst und Denkmalpflege (3/4) 2019; Bundesdenkmalamt: Wien, Austria, 2019.

8. Meingast, R. Nachweis historischer Lehmbautechniken in Ostösterreich. In Lehmbau Tradition und Moderne; Muzeum Vesnice Oblasti Wienviertel Niedersulz GmbH: Niedersulz, Austria, 2014; pp. 21-27.

9. Feiglstorfer, H.; Meingast, R.; Ottner, F. Lehmbau: Der Einfluss von Lehm auf die vormoderne Baukultur in Ostösterreich. In MEMO Medieval and Early Modern Material Culture Online; MEMO: Salzburg, Austria, 2020.

10. Delgado, M.; Guerrero, I. Earth building in Spain. Constr. Build. Mater. 2006, 20, 679-690. [CrossRef]

11. Costa, C.S.; Rocha, F.; Varum, H.; Velosa, A. Influence of the mineralogical composition on the properties of adobe blocks from Aveiro, Portugal. Minerals 2013, 48, 749-758. [CrossRef]

12. Costa, C.S.; Rocha, F.; Velosa, A.L. Sustainability in earthen heritage conservation. Sustainable Use of Traditional Geomaterials in Construction Practice. Geol. Soc. Spec. Publ. 2016, 416, 91-100. [CrossRef]

13. Fratini, F.; Pecchioni, R.L.; Tonietti, U. The earth in the architecture of the historical centre of Lanezia Terme (Italy): Characterization for restoration. Appl. Clay Sci. 2011, 53, 509-516. [CrossRef] 
14. Feiglstorfer, H. Traditionelles Bauen im Freilichtmuseum Bad Tatzmannsdorf. In Freilichtmuseum Bad Tatzmannsdorf. Bautraditionen im Südburgenland; Lehner, E., Feiglstorfer, H., Eds.; New Academic Press: Vienna, Austria, 2021; IVA-ICRA.

15. Lerch, S. Lehmbau in ländlichen Siedlungsstrukturen des Weinviertels. Dokumentation und Analyse eines Lehmhauses in Großriedenthal. Bachelor Thesis, University of Natural Resources and Life Sciences, Institute for Applied Geology, Vienna, Austria, 2018.

16. Wessely, G. Geologie der Österreichischen Bundesländer: Niederösterreich; Geologische Bundesanstalt: Vienna, Austria, 2006.

17. Heinrich, M.; Hofmann, T.; Roetzel, R. Geologie und Weinviertel; Geologische Bundesanstalt und Weinkomitee Weinviertel: Vienna, Austria, 2004.

18. GBA. Geologische Karte von Niederösterreich. Niederösterreich Nord, 1:200000; Geologische Bundesanstalt: Vienna, Austria, 2002.

19. GBA. Geologische Karte von Günserndorf, 1:75000; Geologische Bundesanstalt: Vienna, Austria, 1954.

20. GBA. Geologische Karte der Republik Österreich. Tulln, 1:50000; Geologische Bundesanstalt: Vienna, Austria, 2015.

21. GBA. Geologische Karte der Republik Österreich. Hollabrunn, 1:50000; Geologische Bundesanstalt: Vienna, Austria, 1998.

22. Schönlaub, H.P. Geologie der österreichischen Bundesländer: Burgenland; Geologische Bundesanstalt: Vienna, Austria, 2000.

23. Pahr, A.; Hermann, P. Geologisch-tektonischer Überblick. In Geologie der österreichischen Bundesländer: Burgenland; Schönlaub, H.P., Ed.; Geologische Bundesanstalt: Vienna, Austria, 2000; pp. 10-11.

24. GBA. Geologie der Österreichischen Bundesländer. Burgenland, 1:200000; Geologische Bundesanstalt: Vienna, Austria, 2000.

25. GBA. Geologische Karte der Republik Österreich. Rechnitz, 1:50000; Geologische Bundesanstalt: Vienna, Austria, 1988.

26. Ecker, U. Historischer Lehmbau im Weinviertel. Rekonstruktion, Materialverwendung und Datierung mit Hilfe der Dendrochronologie. Master's Thesis, University of Natural Resources and Life Sciences, Institute for Applied Geology, Vienna, Austria, 2017.

27. Rauter, T.; Schößwendter, J. Lehmbau im Weinviertel. Aufnahme von Lehmbauten/Lössvorkommen und Untersuchung der gewonnenen Lehm-bzw. Lössproben. Bachelor Thesis, University of Natural Resources and Life Sciences, Institute for Applied Geology, Vienna, Austria, 2015.

28. Christoph, G.; Ben, H. Lehmbau im Weinviertel. Aufnahme von Lehmbauten/Lössvorkommen und Untersuchung der gewonnenen Lehm-bzw. Lössproben. Bachelor Thesis, University of Natural Resources and Life Sciences, Institute for Applied Geology, Vienna, Austria, 2019.

29. Whittig, L.D. X-ray diffraction techniques for mineral identification and mineralogical identification. In Methods of Soil Analysis; Black, C.A., Ed.; Amer. Soc. Agron.: Madison, WI, USA, 1965; pp. 671-698. [CrossRef]

30. Tributh, H. Notwendigkeit und Vorteil der Aufbereitung von Boden-und Lagerstättentonen. In Identifizierung und Charakterisierung von Tonmineralen; Tributh, H., Lagaly, G., Eds.; Berichte der DTTG: Giessen, Deutschland, 1991; pp. 29-33.

31. Thorez, J. Phyllosilicates and Clay Minerals: A Laboratory Handbook for their X-ray Diffraction Analysis; Lelotte: Dison, Belgium, 1975.

32. Brindley, G.W.; Brown, G. Crystal Structures of Clay Minerals and their X-Ray Identification; Mineralogical Society: London, UK, 1980.

33. Moore, D.M.; Reynolds, R.C., Jr. X-ray Diffraction and the Identification and Analysis of Clay Minerals; Oxford University Press: New York, NY, USA, 1997.

34. Wilson, M.J. A Handbook of Determinative Methods in Clay Mineralogy; Verlag Blackie: Glasgow, UK; London, UK, 1987.

35. Riedmüller, G. Neoformations and Transformations of Clay Minerals in Tectonic Shear Zones. TMPM Tschermaks Min. Petr. Mitt. 1978, 25, 219-242. [CrossRef]

36. Van Olphen, H. An Introduction to Clay Colloid Chemistry; John Wiley \& Sons: New York, NY, USA, 1964. 